\title{
TACE/ADAM17 Is Essential for Oligodendrocyte Development and CNS Myelination
}

\author{
Javier Palazuelos, ${ }^{1}$ Howard C. Crawford, ${ }^{2}$ Michael Klingener, ${ }^{1}$ Bingru Sun, ${ }^{1}$ Jason Karelis, ${ }^{1}$ Elaine W. Raines, ${ }^{3}$ \\ and Adan Aguirre ${ }^{1}$ \\ ${ }^{1}$ Department of Pharmacological Sciences, Centers for Molecular Medicine, Stony Brook University, SUNY, New York 11794, ${ }^{2}$ Mayo Clinic Cancer Center, \\ Jacksonville, Florida 32224, and ${ }^{3}$ Department of Pathology, University of Washington, Seattle, Washington 98195
}

\begin{abstract}
Several studies have elucidated the significance of a disintegrin and metalloproteinase proteins (ADAMs) in PNS myelination, but there is no evidence if they also play a role in oligodendrogenesis and CNS myelination. Our study identifies ADAM17, also called tumor necrosis factor- $\alpha$ converting enzyme (TACE), as a novel key modulator of oligodendrocyte (OL) development and CNS myelination. Genetic deletion of TACE in oligodendrocyte progenitor cells (OPs) induces premature cell cycle exit and reduces OL cell survival during postnatal myelination of the subcortical white matter (SCWM). These cellular and molecular changes lead to deficits in SCWM myelination and motor behavior. Mechanistically, TACE regulates oligodendrogenesis by modulating the shedding of EGFR ligands TGF $\alpha$ and HB-EGF and, consequently, EGFR signaling activation in OL lineage cells. Constitutive TACE depletion in OPs in vivo leads to similar alterations in CNS myelination and motor behavior as to what is observed in the EGFR hypofunctional mouse line EgfrWa2. EGFR overexpression in TACE-deficient OPs restores OL survival and development. Our study reveals an essential function of TACE in oligodendrogenesis, and demonstrates how this molecule modulates EGFR signaling activation to regulate postnatal CNS myelination.
\end{abstract}

Key words: ADAM17; cell survival; CNS myelination; EGFR; oligodendrocyte progenitor; TACE

\section{Introduction}

Myelin, produced by oligodendrocytes (OLs) in the CNS, insulates neuronal axons and is essential for rapid and efficient transmission of action potentials as well as proper neuronal activity (Nave, 2010). Deficits in myelination lead to neuronal dysfunction, axonal degeneration, deterioration of neurological functions, and behavioral deficits (Nave and Trapp, 2008; Yamazaki et al., 2010; Liu et al., 2012). The precise understanding of OL development and integrity is essential, as emphasized by the prevalence of neurological diseases caused by malformation or deterioration of myelin sheaths, including multiple sclerosis, leukodystrophies, and complex neuropsychiatric disorders (Nave and Trapp, 2008; Emery, 2010).

It is largely recognized that the transition from oligodendrocyte progenitor cells (OPs) into mature myelinating OLs is an important step for myelination and remyelination (Franklin and ffrench-Constant, 2008; Emery, 2010; Fulton et al., 2010; Fancy et

Received March 17, 2014; revised June 18, 2014; accepted July 3, 2014.

Author contributions: J.P. and A.A. designed research; J.P., M.K., B.S., J.K., and A.A. performed research; H.C.C. and E.W.R. contributed unpublished reagents/analytic tools; J.P., M.K., and A.A. analyzed data; J.P. and A.A. wrote the paper.

This work was supported by National Institutes of Health 4R00NS057944-03 (A.A.) and the National Multiple Sclerosis Society (J.P.). We thank Dr. Gallo (Children's National Medical Center, Washington DC) for the CNP-EGFP mouse line. We are grateful to H. Colognato, S. Tsirka, and M. Frohman from the Pharmacology Department at SUNY, Stony Brook, for critically reading this manuscript.

The authors declare no competing financial interests.

Correspondence should be addressed to Adan Aguirre, PhD, Department of Pharmacological Sciences, Centers for Molecular Medicine, Stony Brook University, SUNY, NY 11794. E-mail: adan.aguirre@stonybrook.edu.

DOI:10.1523/JNEUROSCI.1220-14.2014

Copyright $\odot 2014$ the authors $\quad 0270-6474 / 14 / 3411884-13 \$ 15.00 / 0$ al., 2011; Miron et al., 2011). During tissue development and repair, the accuracy and proper timing of OP expansion and OL differentiation, together with cell survival during these processes, are critical for tissue function, homeostasis, and repair (Fancy et al., 2011). However, the molecular mechanisms that regulate these processes, and consequently, OL development and myelination, are still not completely understood. Therefore, there is a need to identify molecular targets that modulate OL lineage cell survival and OP expansion and differentiation to design cellbased strategies to promote remyelination in demyelinating disorders.

Several studies have elucidated the significance of ADAMs proteins in myelination, particularly in the PNS, but little is known about their role in CNS myelination. ADAM10 is expressed in high abundance in the PNS, although it does not seem to be critical for PNS myelination (Jangouk et al., 2009; Luo et al., 2011). Knock-out mice that lack expression of ADAM19 display normal myelination but show a delay during the process of remyelination in experimental models of demyelination (Wakatsuki et al., 2009). Additionally, ADAM22 has been directly implicated in myelination, as mice lacking ADAM22 present with hypomyelination in the PNS (Sagane et al., 2005). Finally, it has been recently demonstrated that downregulation of TACE in motor neurons in the PNS leads to precocious myelination by cleaving Neuregulin1 type III (La Marca et al., 2011). However, the biological, developmental, and regenerative role of ADAM proteins in oligodendrogenesis and CNS myelination has never been reported.

Our study identifies TACE/ADAM17 as a critical player for proper OL development and CNS myelination. By generating 
two new transgenic mouse lines in which TACE gene expression is selectively deleted in OPs, we identify an essential function of TACE in modulating OP cell cycle exit and OL lineage cell survival during subcortical white matter (SCWM) development, and, therefore, for functional CNS myelination. Furthermore, our study here shows an essential function of TACE in the shedding of EGFR ligands and for EGFR signaling activation in OL lineage cells during SCWM development. EGFR overexpression in TACE-deficient OPs restores cell survival, proliferation, and development, confirming the relevance of this pathway in the modulation of oligodendrogenesis and CNS myelination.

\section{Materials and Methods}

Animals. All animal procedures were performed according to the Institutional Animal Care and Use Committee of DLAR, SUNY Stony Brook School of Medicine, and the NIH Guide for the Care and Use of Laboratory Animals. Generation and characterization of CNP-EGFP (RRID: MGI MGI:3850679; Yuan et al., 2002), NG2-dsRed (RRID: IMSR JAX: 008241; Zhu et al., 2008), and TACE ${ }^{\mathrm{fl} / \mathrm{fl}}$ (Peschon et al., 1998; Ardito et al., 2012) mouse lines was done as previously reported. The NG2-Cre (RRID:IMSR JAX:008533; Zhu et al., 2008), Wa2 (JAX:000317; Luetteke et al., 1994; Aguirre and Gallo, 2007; EgfrWa2), and PDGFR $\alpha$ creERT2 (Rivers et al., 2008) mice were obtained from The Jackson Laboratories). Males and females were used for the analysis. Genotyping of these transgenic mice was performed by PCR. The recombination efficiency in PDGFR $\alpha-\mathrm{Cre}^{\mathrm{tm}}: \mathrm{TACE}^{\mathrm{f} / \mathrm{fl}}: \mathrm{YFP}$ and PDGFR $\alpha-\mathrm{Cre}^{\mathrm{tm}}: \mathrm{TACE}^{\mathrm{w} / \mathrm{w}}$ : YFP control mice was calculated after injection of tamoxifen (TAM; 20 $\mathrm{mg} / \mathrm{kg}$ ) into P6 male and female pups for 3 consecutive days (24 h apart). Mice were killed at $24 \mathrm{~h}$ after the last tamoxifen injection (P9) to calculate the percentage of recombined $\mathrm{YFP}^{+}$cells in the developing SCWM. The percentage of $\mathrm{YFP}^{+} \mathrm{NG}_{2}{ }^{+}$/total NG2 ${ }^{+}$cells was used as a reference to determine the efficiency of recombination in this mouse line. Our data revealed that $\sim 88.2 \pm 4.1 \%$ of the $\mathrm{NG}^{+}$population was $\mathrm{YFP}^{+}$in the SCWM at this developmental stage.

$B r d U$ administration in vivo. The BrdU labeling protocol was performed as previously described (Aguirre et al., 2007; Palazuelos et al., 2014). For proliferation studies, BrdU was injected intraperitoneally at $100 \mathrm{mg} / \mathrm{kg}$ and tissue was processed for histological procedures $2 \mathrm{~h}$ following the injection. For cell cycle exit studies, BrdU was injected first and $3 \mathrm{~h}$ later mice received TAM for $2 \mathrm{~d}$ and tissue was analyzed $48 \mathrm{~h}$ later to quantify the percentage of OPs that exit the cell cycle $\left(\mathrm{BrdU}^{+} \mathrm{Ki}^{-} 7^{-}\right.$ $\mathrm{BrdU}^{+}$cells; Palazuelos et al., 2012).

Western blot. SCWM tissue (from TACE-deficient mice and control littermates) was microdissected from $200-\mu$ m-thick coronal sections, and tissue was used for whole-protein extraction using RIPA lysis buffer (Santa Cruz Biotechnology) with inhibitors: PMSF in DMSO, protease inhibitors, and sodium orthovanadate were as recommended by the manufacturer (Santa Cruz Biotechnology ). Protein samples $(15 \mu \mathrm{g})$ were separated on $10 \%$ acrylamide (Bio-Rad) gels and transferred to PVDF membranes (Millipore). Antibodies were used for detection of the indicated proteins on PVDF membranes. Primary antibodies were used in combination with secondary horseradish peroxidase-conjugate antibodies to detect the protein in question using an enhanced chemiluminescence substrate mixture (ECL Plus; GE Healthcare; Santa Cruz Biotechnology; 1:5000). Protein levels in question were quantified and expressed as arbitrary units (a.u.) after actin normalization. HB-EGF and TGF $\alpha$ shedding in the SCWM was determined by Western blot (WB) analysis by calculating the ratio between their respective cleaved versus uncleaved forms, then normalized to actin levels and expressed in a.u.

Immunohistochemistry. For characterization of OL lineage cells, brain tissue was processed as previously described (Aguirre et al., 2007). In brief, $30-\mu \mathrm{m}$-thick brain sections were incubated with the indicated primary antibodies (overnight at $4^{\circ} \mathrm{C}$ ). The following day, sections were washed and incubated with fluorescent secondary antibodies to reveal and detect the antigens in question in situ using confocal microscopy. The primary antibodies used are as follows: anti-NG2 (AB_91789) and
anti-GalC (AB_90632; Millipore); anti-BrdU (AB_609568; Accurate), anti-MBP (AB_510039), and anti-CNP (AB_510037; Covance); totalEGFR (AB_764519), anti-MOG (AB_2282105; Epitomics), anti$\operatorname{PDGFR} \alpha$ (AB 631064), and anti HB-EGF (AB_354429; R\&D systems); anti-Ki67 (AB_442102; Novocastra); anti-CC1 (AB_213434; Calbiochem); anti-Caspase3 (RRID:AB_2069872), anti-pEGFR (AB_2096270), and anti-YFP (AB_1196615;Cell Signaling Technology); and polyclonal anti-Adam17 (AB_302796; Abcam), anti-Iba-1 (AB_2314666; Wako), anti-TGF $\alpha$ (AB_630289), and HB-EGF(AB_2114608; Santa Cruz Biotechnology) antibodies. The appropriate mouse, rat, and rabbit highly cross-adsorbed Alexa Fluor 488, Alexa Fluor 547, and Alexa Fluor 647 secondary antibodies (Invitrogen) were used where appropriate.

Immunocytochemistry. Cells were plated onto poly-L-lysine-coated glass coverslips (Sigma) to test both proliferation and cell survival. At the conclusion of the respective experiments, cells were fixed with $4 \%$ PFA and then incubated with $20 \%$ goat serum for $10 \mathrm{~min}$ at room temperature. The coverslips were then processed with primary antibody followed by secondary antibody incubation.

FAC-sorting and cell cultures. FAC-sorting purification of CNP-EGFP ${ }^{+}$ low (OPs), CNP-EGFP ${ }^{+}$high (OLs), and PDGFR $\alpha$-Cre::YFP ${ }^{+}: \mathrm{NG}^{+}$ cells was performed as previously described (Aguirre et al., 2010; Palazuelos et al., 2014). For TACE ${ }^{\mathrm{fl} / \mathrm{fl}}$ versus TACE ${ }^{\mathrm{w} / \mathrm{w}}$ OP culture experiments, 6-d-old PDGFR $\alpha$-cre ${ }^{\mathrm{tm}}: \mathrm{TACE}^{\mathrm{fl} / \mathrm{fl}}$ and control pups received TAM for 2 consecutive days, and SCWM was microdissected $24 \mathrm{~h}$ after the last TAM injection and processed for single-cell dissociation and immunolabeling with anti-NG2 antibodies. Cell suspensions were analyzed for light forward and side scatter using a FACStar plus instrument (Becton Dickinson). Purified CNP-EGFP ${ }^{+}$and $\mathrm{YFP}^{+}$cells were used for either cell culture experiments or real-time (RT)-PCR analysis. The purity of OL lineage FAC-sorted cells and OP cultures was confirmed by RT-PCR and immunofluorescence analysis. RT-PCR analysis of OL and astroglial and microglial cell markers evidenced a high enrichment of OL lineage cells and the absence of other glial cells in our OP and pre-OL sorted cells (data not shown). Similar results were obtained from PDGFR $\alpha$ :YFP:NG2 ${ }^{+}$ OP FAC-sorted cells. FAC-sorted cells were cultured for $24 \mathrm{~h}$ and the purity of cell cultures was analyzed by immunofluorescence analysis. Analysis with anti-PDGFR $\alpha$ and anti-GalC antibodies revealed that $96.1 \pm 2.1$ and $95.8 \pm 2.8 \%$ of the wt and fl/fl NG2 ${ }^{+} \mathrm{YFP}^{+}$cells, respectively, were positive for OP cell makers (PDGFR $\alpha$ or GalC; from total $\mathrm{DAPI}^{+}$plated cells; data not shown). The purity of $C N P$-EGFP ${ }^{\text {low }}(\mathrm{OPs})$ and CNP-EGFP high (OLs)-sorted cells was $95.2 \pm 1.8 \%\left(\mathrm{EGFP}^{+} \mathrm{DAPI}^{+}\right.$, $\mathrm{DAPI}^{+}$cells). Cells were seeded $(20,000$ cells/well $)$ on poly-L-lysinecoated coverslips in 24-well plates (BD Falcon) and maintained in Neurobasal medium with N2 and B27 and 1.5\% FBS (Supplements; Invitrogen) for several days in vitro as indicated in each experiment. When FAC-sorted cells were maintained under conditions of proliferation we used PDGF $(2.5 \mathrm{ng} / \mathrm{ml})$ and bFGF2 $(10 \mathrm{ng} / \mathrm{ml})$. When cells were cultured under differentiation conditions, cell cultures were supplemented with NT-3 $(10 \mathrm{ng} / \mathrm{ml})$ and T3 $(30 \mathrm{ng} / \mathrm{ml})$. In vitro cell proliferation assays were performed by adding BrdU at $200 \mathrm{ng} / \mathrm{ml}$ for $6 \mathrm{~h}$ before the end of the experiment. After culture, cells were processed for immunocytochemistry analysis.

Retrovirus production and infection. OP cultures were stably transduced using GFP retrovirus (Aguirre et al., 2007; Ivkovic et al., 2008) by directly adding viral particles to the cell culture media twice, $24 \mathrm{~h}$ apart. EGFR-GFP and CLE-GFP plasmids were a kind gift from Dr. Sally Temple (Neural Stem Cell Institute, Rensselaer New York; Sun et al., 2005; Ivkovic et al., 2008). Replication-deficient viruses with vsv-G coats were generated from these constructs as previously described (Aguirre et al., 2007). EGFR-GFP retrovirus stocks were assayed with NIH 3 T3 cells with $2 \mu \mathrm{l}$ of $1-2 \times 10^{6} \mathrm{cfu} / \mathrm{ml}$. OP cell cultures were infected with either EGFR-GFP or CLE-GFP as indicated. Then, cell cultures were maintained under proliferating or differentiating conditions for $1 \mathrm{~d}$ or $3 \mathrm{~d}$, respectively, and cell proliferation, survival, and development were analyzed by immunofluorescence analysis.

Microscopy and cell counting. A confocal laser-scanning microscope TCS-SP5 (Leica DMI6000 B instrument) was used for image localization of FITC (488 nm laser line excitation; 522/35 emission filter), Cy3 (570 nm excitation; 605/32 emission filter), and Cy5 (647 exci- 
A

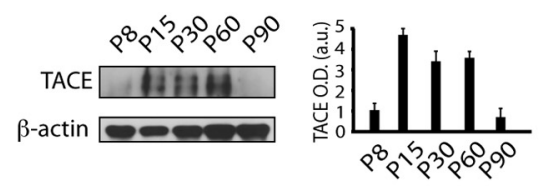

F

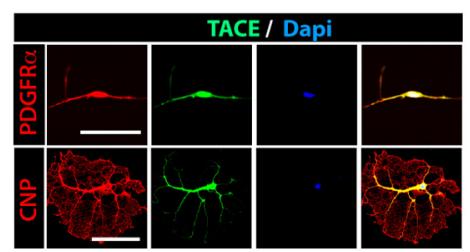

C

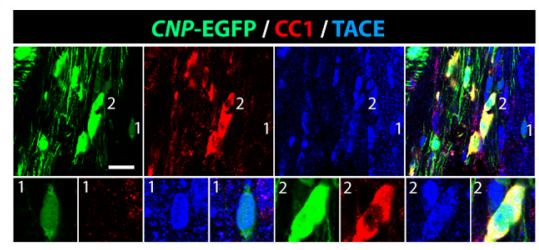

G

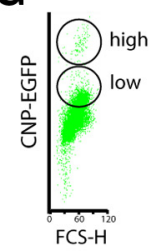

H

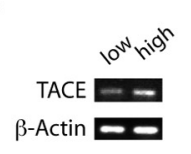

I

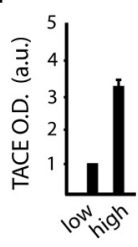

D

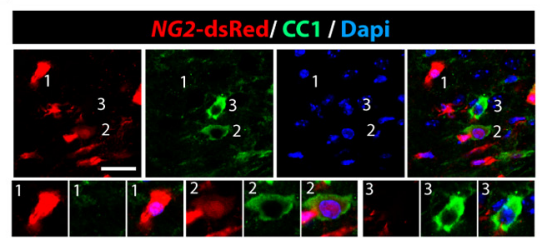

E

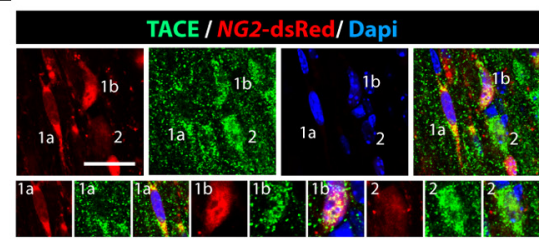

Figure 1. TACE/ADAM17 is expressed by $0 \mathrm{~L}$ lineage cells during SCWM development. $A, B, W B$ analysis and quantification of TACE expression from SCWM protein extracts obtained at P8 -P90. $\mathbf{C}-\boldsymbol{E}$, Characterization by immunofluorescence analysis of TACE expression in $0 \mathrm{~L}$ lineage cells during SCWM development. Immunofluorescence with anti-TACE and CC1 antibodies at P15 in the SCWM of CNP-EGFP ( () and NG2-dsRed (D, E) mice. OPs are characterized by NG2 expression and low CNP-EGFP expression levels and pre-OLs by CC1 expression and high CNP-EGFP levels (C, D). TACE is expressed by both OP cells (CNP-EGFP low $C C 1^{\text {neg }}$, C1; NG2-dsRed ${ }^{\text {high }}$, D1, E1a, E1b) and premyelinating OLs (CNP-EGFP high $C C 1^{+}, C 2$; NG2-dsRed ${ }^{\text {low }}$, D2, E2). D3, Represents a mature 0L, characterized CC1 expression, and NG2-dsRed ${ }^{\text {neg }}$. $\boldsymbol{F}$, Characterization of TACE expression during $0 \mathrm{~L}$ development in vitro. NG2 ${ }^{+}$cells were FAC-sorted at P8 from the SCWM. $\boldsymbol{F}$, Top, Immunofluorescence analysis with anti-TACE antibodies shows TACE expression in OPs (PDGFR $\alpha^{+}$). F, Bottom, FAC-sorted NG2 ${ }^{+}$cells were also maintained in culture under differentiation conditions for $4 \mathrm{~d}$ to allow $0 \mathrm{~L}$ differentiation. This analysis showed that TACE is also expressed in cells undergoing $0 \mathrm{~L} \mathrm{differentiation} \mathrm{(CNP}{ }^{+}$cells). $G$, A typical FACS plot diagram of CNP-EGFP ${ }^{+}$cells isolated from SCWM of the CNP-EGFP mouse at P4.H,I,RT-PCR analysis and quantification of TACE from CNP-EGFP low (OPS) and CNP-EGFP high (OLS) FAC-sorted cells. Data are shown as mean \pm SEM, $n=5$ brains for each time point and three independent experiments. Scale bars: $\boldsymbol{C}-\boldsymbol{E}, 10 \mu \mathrm{m} ; \boldsymbol{F}, 5 \mu \mathrm{m}$.

tation; 680/32 emission filter). Optical sections $(z=0.5 \mu \mathrm{m})$ of confocal epifluorescence images were sequentially acquired using a $63 \times$ objective (NA 1.40), with LAS AF software. ImageJ software was then used to overlap collected images. Merged confocal images were processed in Photoshop Cs4 software (Adobe) with minimal manipulation of contrast. At least six different brains for each strain and each experimental condition were analyzed and counted. Cell counting was performed blindly, and tissue sections were matched across samples. An average of $8-10$ sections were quantified using unbiased stereological morphometric analysis for the SCWM to obtain an estimate of the total number of positive cells. All cell-density quantification data were obtained by cell counting using ImageJ, and data are presented as the mean cell number per cubic millimeter $(\times 1000$; Aguirre et al., 2007, 2010).

$q R T-P C R$ and semiquantitative PCR analysis. mRNA was isolated from FAC-sorted cells, CNP-EGFP ${ }^{\text {low }}(\mathrm{OPs})$, and CNP-EGFP ${ }^{\text {high }}(\mathrm{OLs})$ by using TRIzol (Invitrogen). RNA from each sample was reverse transcribed using the SuperScript First-Strand cDNA Synthesis kit (Invitrogen). Mouse gene-specific primers were obtained from Integrated DNA Technologies. Semiquantitative PCR amplifications were performed using the following conditions: $93^{\circ} \mathrm{C}$ for $1 \mathrm{~min}$, two rounds $\left(30 \mathrm{~s}\right.$ at $59^{\circ} \mathrm{C}, 1$ min at $72^{\circ} \mathrm{C}$, and $30 \mathrm{~s}$ at $\left.93^{\circ} \mathrm{C}\right)$, two rounds $\left(30 \mathrm{~s}\right.$ at $57^{\circ} \mathrm{C}, 1 \mathrm{~min}$ at $72^{\circ} \mathrm{C}$, and $30 \mathrm{~s}$ at $\left.93^{\circ} \mathrm{C}\right)$, and $35 \mathrm{cycles}\left(30 \mathrm{~s}\right.$ at $55^{\circ} \mathrm{C}, 1 \mathrm{~min}$ at $72^{\circ} \mathrm{C}$, and $30 \mathrm{~s}$ at $93^{\circ} \mathrm{C}$ ). After a final extension step at $72^{\circ} \mathrm{C}$ for $5 \mathrm{~min}$, PCR products were separated on $1.5 \%$ agarose gels. qRT-PCR was performed with the SYBR Green system. Amplifications were run in a LightCycler 480 Real-time PCR system (Roche), and the values obtained were adjusted using $18 \mathrm{~S}$ and $\beta$-actin mRNA levels as references. The sequences of the primers used are as follows: TACE forward primer $5^{\prime}$ - TGTGGTTATTTAAATGCAGATAGTGA-3'; TACE reverse primer 5' TCACTCGACGAACAAACTCTTC-3'; HB-EGF forward primer $5^{\prime}$-CTCTTGGCCCTT AGAGAGGAG-3'; HB-EGF reverse primer 5'-ACTGGAGTGTGGG TGTAGGG-3'; TGF $\alpha$ forward primer $5^{\prime}$-CCTGGTGGTGGTCTCCA TT-3'; TGF $\alpha$ reverse primer 5' - CAGTGTTTGCGGAGCTGA-3'.

PMA-induced EGFR ligands shedding analysis. PMA (Sigma) was dissolved in DMSO at $2 \mu \mathrm{g} / \mu \mathrm{l}$ and stored at $-20^{\circ} \mathrm{C}$. For in vitro experiments PMA was used at $20 \mathrm{ng} / \mathrm{ml}$ and for in vivo experiments it was administered at $0.15 \mathrm{mg} / \mathrm{kg}$ by intraperitoneal injection. HB-EGF shedding detection in vitro was analyzed at $1 \mathrm{~h}$ after treatment by ELISA analysis (CUSABIO) using supernatant from wt and fl/fl cell cultures, treated with either vehicle or PMA.
Behavioral test, Open Field Test. To measure general motor activity, we used the Open Field apparatus (Tress et al., 2012). P30 mice ( $n=10$ each group) were placed on a corner of a $40 \mathrm{~cm}^{2}$ gridded arena and monitored for 10 min using an EthoVision XT system (Noldus). Motor behavior was measured as velocity (mean velocity in $10 \mathrm{~min}$ ) and fast movements (time moving faster than $4 \mathrm{~cm} / \mathrm{s}$ ).

Statistics. Results are shown as the mean \pm SEM. The number of experiments and number of animals used for each experiment are indicated in the figure legends. Statistical analysis was performed by one-way or two-way ANOVA as appropriate. A post hoc analysis was made by the Student-Newman-Keuls test.

\section{Results}

\section{TACE/ADAM17 is expressed by OL lineage cells during}

\section{SCWM myelination}

To determine whether TACE is involved in oligodendrogenesis and CNS myelination, we first analyzed the pattern of expression of TACE in the SCWM at different developmental stages. WB analysis of SCWM extracts from P8-P90 revealed an expression pattern of TACE, which peaked during the critical periods of SCWM myelination (Fig. $1 A, B$ ). We next characterized TACE expression in OL lineage cells by immunofluorescence analysis in the SCWM of transgenic reporter mice, in which promoters of $\mathrm{OL}$ markers drive the expression of fluorescent proteins in $\mathrm{OL}$ lineage cells (CNP-EGFP and NG2-dsRed mice). The CNP-EGFP mouse line, based on EGFP intensity, allows for the identification of OPs (CNP-EGFP ${ }^{\text {low; }}$ Fig. 1C1) and pre-OLs CNP-EGFP hight (Fig. 1C2; Yuan et al., 2002). In the NG2-dsRed mouse line, the red fluorescence is only present in OPs (Fig. 1D1) and not in their progeny, whose signal decreases during OL differentiation (Fig. 1D2,D3; Zhu et al., 2008). Immunofluorescence analysis in the SCWM at P15 evidenced that TACE is expressed in both OPs

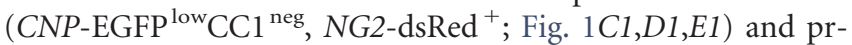
emyelinating OLs $\left(C N P\right.$-EGFP ${ }^{\text {high }} \mathrm{CC}^{+}{ }^{+}, N G 2$-dsRed ${ }^{\text {neg }} \mathrm{CC} 1^{+}$; Fig. 1C2,D2,D3,E2). Of note, higher TACE levels were observed in cells transitioning to premyelinating OLs in the developing SCWM (Fig. 1C,E). We confirmed these results by establishing primary $\mathrm{OP}$ cell cultures from $\mathrm{NG} 2{ }^{+} \mathrm{FAC}$-sorted cells obtained 
A

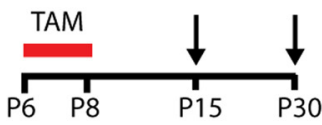

C

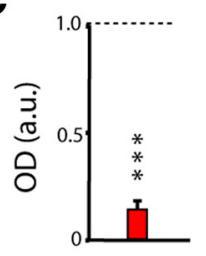

D

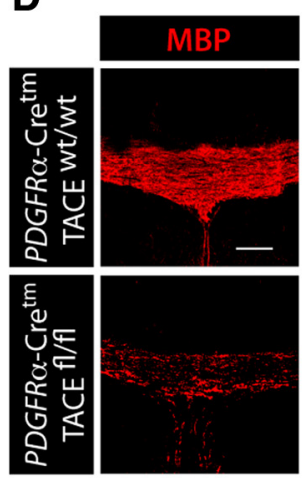

G

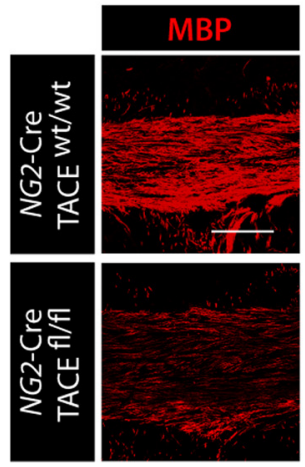

E

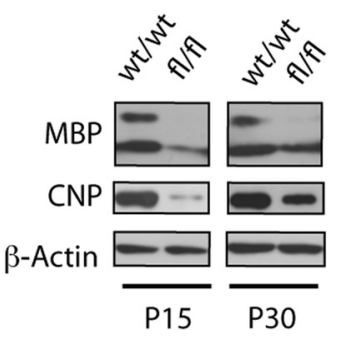

F
PDGFR $\alpha-C r \mathrm{e}^{\mathrm{tm}}:: \mathrm{TACE} \mathrm{E}^{\mathrm{fl} / \mathrm{fl}}$ vs wt

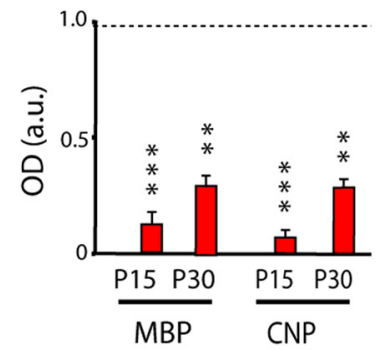

J

H

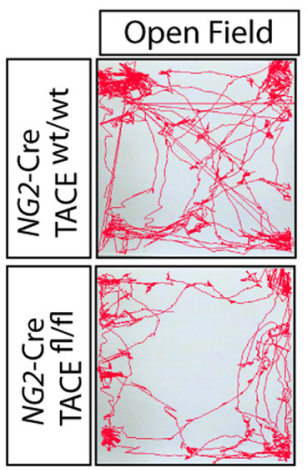

I

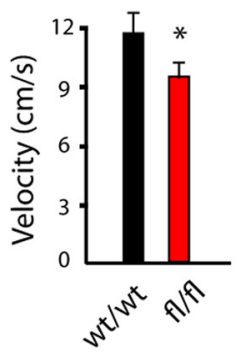

Figure 2. TACE deficiency in OPs leads to deficits in postnatal CNS myelination and motor function. $\boldsymbol{A}-\boldsymbol{F}$, Time line depicting the TAM (red bar) treatment paradigm and time points of analysis (arrows). TAM was injected three times $24 \mathrm{~h}$ apart into control

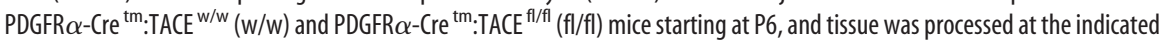
time points (arrows, P15 and P30). B, C, WB analysis of TACE levels of microdissected SCWM at 1 week after TACE deletion (P15) evidenced high TACE depletion in fl/fl SCWM compared with control. $\boldsymbol{D}$, Representative confocal images with anti-MBP antibodies in the SCWM of control and fl/fl mice at 3 weeks after deletion of TACE (P30). E, F, WB analysis of microdissected SCWM at 1 and 3 weeks after TACE deletion (P15 and P30, respectively) showed reduced levels of MBP and CNP proteins in $\mathrm{fl} / \mathrm{fl}$ mice compared with controls. Histograms are expressed as arbitrary units (a.u.) after actin normalization. $\mathbf{G}$, Representative confocal images with anti-MBP antibodies in the SCWM of NG2-Cre:TACE ${ }^{\mathrm{fl} / \mathrm{fl}}$ and control mice at P30. $\boldsymbol{H}-\boldsymbol{J}$, The Open Field

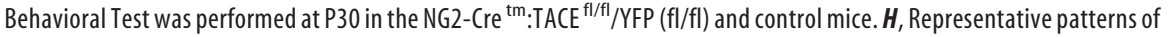
motor activity in the Open Field apparatus. I, Velocity was measured as the mean velocity in a 10 min test trial. $J$, Time performing fast movements, defined as movement faster than $4 \mathrm{~cm} / \mathrm{s}$. Data are shown as mean $\pm S E M ; n=10$ mice for each time point and three independent experiments. Scale bars: $100 \mu \mathrm{m} .{ }^{*} p<0.05,{ }^{* *} p<0.01$, and ${ }^{* * *} p<0.001$ versus control (w/w) mice.

from the SCWM. Consistent with our analysis in vivo, TACE expression was observed in OPs (PDGFR $\alpha^{+}$cells) and cells undergoing $\mathrm{OL}$ differentiation $\left(\mathrm{CNP}^{+}\right.$cells; Fig. $\left.1 F\right)$. Finally, to quantify TACE expression levels during OL differentiation, we isolated $C N P-E G F P^{\text {low }}$ (OPs) and $C N P-E G F P^{\text {high }}(\mathrm{OLs})$ from the SCWM of P5 CNP-EGFP mice (Fig. 1G). RT-PCR analysis confirmed that TACE is expressed by OPs but TACE mRNA levels were increased in pre-OLs (Fig. 1H,I). These results point to a role for TACE in OL development and SCWM myelination.

TACE/ADAM17 is essential for postnatal CNS myelination To directly define whether TACE plays a role in OL development and CNS myelination, we generated a new mouse line (PDGFR $\alpha$ -

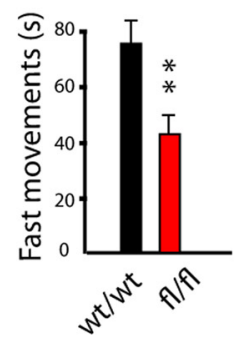

Cre $^{\mathrm{tm}}: \mathrm{TACE}^{\mathrm{fl} / \mathrm{fl}}: \mathrm{YFP} ; \mathrm{fl} / \mathrm{fl}$ mice), to ablate TACE expression in OPs upon Tamoxifen (TAM) administration. In this mouse line, TAM-mediated recombination also induces YFP expression allowing for the identification and tracking of recombined cells in both $\mathrm{fl} / \mathrm{fl}$ mice and their control littermates (w/w; Fig. 2A). We first confirmed the high recombination efficiency in the SCWM of $\mathrm{fl} / \mathrm{fl}$ mice at P15 compared with their wt littermates (Fig. 2A-C; see also Materials and Methods). To determine the role of TACE in oligodendrogenesis and myelination, control and $\mathrm{fl} / \mathrm{fl}$ mice received TAM at P6 for 3 consecutive days, and SCWM myelination was analyzed at 1 week (P15) and 3 weeks (P30) after the last TAM injection (Fig. 2A). Immunofluorescence and $\mathrm{WB}$ analysis at P15 and P30 evidenced reduced myelinrelated protein levels [myelin basic protein (MBP), 2', 3'-cyclic nucleotide $3^{\prime}$ phosphosdiesterase (CNP)] in the SCWM of fl/fl mice compared with their wt littermates (Fig. 2D-F). To confirm these results, we generated a second mouse line in which TACE is constitutively deleted in $\mathrm{NG}_{2}{ }^{+}$OPs under the expression of the NG2 promoter (NG2-Cre:TACE ${ }^{\mathrm{fl} / \mathrm{fl}}$ ). Consistent with our data using the inducible PDGFR $\alpha-\mathrm{Cre}^{\mathrm{tm}}: \mathrm{TACE}^{\mathrm{fl} / \mathrm{fl}}:$ YFP mouse line, constitutive deletion of TACE in OPs (NG2-Cre:TACE ${ }^{\mathrm{f} / \mathrm{fl}}$ mouse) revealed deficits in postnatal SCWM myelination compared with control littermates (Fig. 2G).

Several reports have demonstrated that defects in postnatal CNS myelination lead to behavioral alterations in rodents (Fahlström et al., 2011; Liu et al., 2012; Scafidi et al., 2014). By using the Open Field Test we analyzed whether the SCWM myelination deficiencies observed in $\mathrm{fl} / \mathrm{fl}$ mice could also lead to alterations in motor performance. Interestingly, we observed a reduction in velocity and fast movements in NG2 cre: $\mathrm{TACE}^{\mathrm{fl} / \mathrm{fl}}$ mice at $\mathrm{P} 30$ compared with control mice (Fig. $2 \mathrm{H}-\mathrm{J}$ ). Our data here indicate that TACE exerts an essential function in modulating OL development and functional CNS myelination.

\section{TACE/ADAM17 deficiency in OPs induces premature cell} cycle exit

To define the mechanisms by which TACE regulates CNS myelination, we analyzed OL development in the SCWM of TACE-deficient mice. To this end, PDGFR $\alpha$-Cre ${ }^{\mathrm{tm}}: \mathrm{TACE}^{\mathrm{fl} / \mathrm{fl}}$ : YFP and control mice received TAM at P6 for 3 consecutive days, and we characterized the $\mathrm{YFP}^{+}$population in the SCWM at 1 week after TACE deletion in OPs (Fig. 3A). A significant twofold reduction in the number of recombined $\mathrm{YFP}^{+}$cells and $\mathrm{CC}{ }^{+} \mathrm{OLs}$ was observed in the SCWM of fl/fl mice when 
A

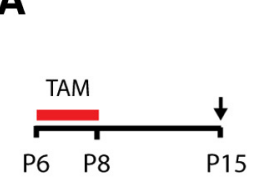

B

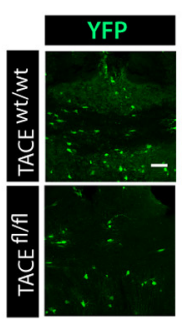

G

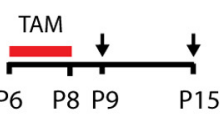

C

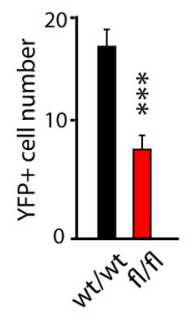

D

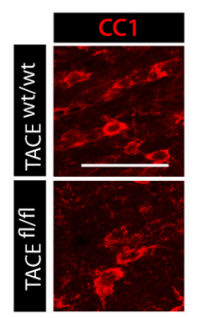

H

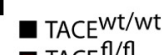

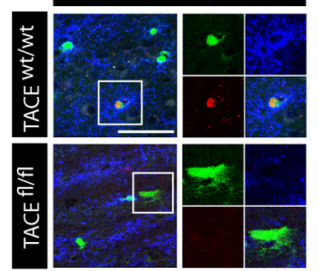

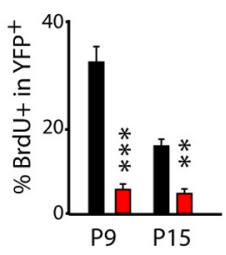

K

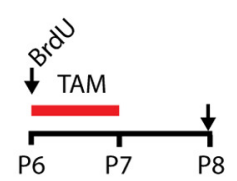

L

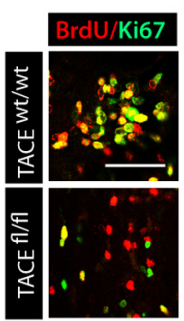

M

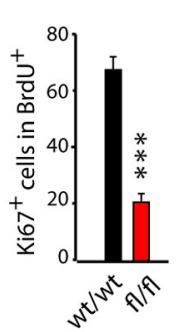

N

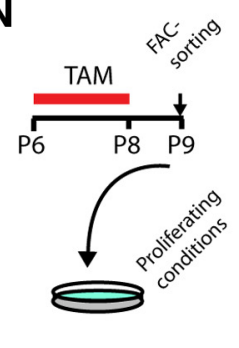

E

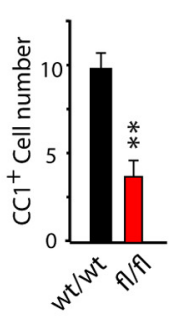

I

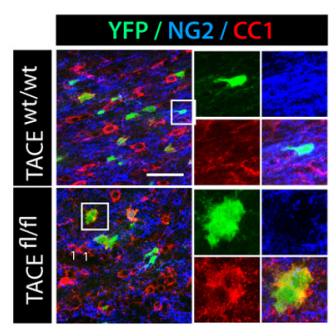

J

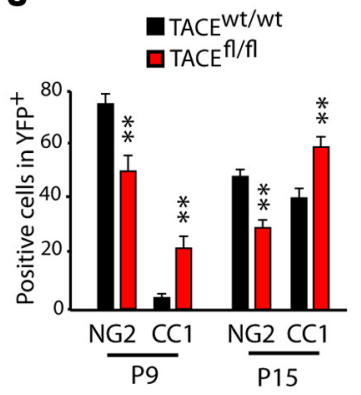

0

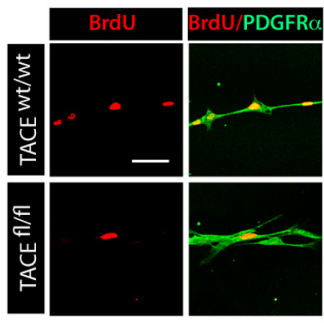

P

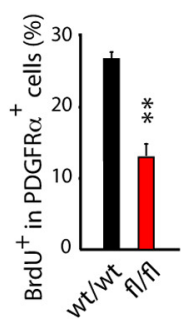

Q

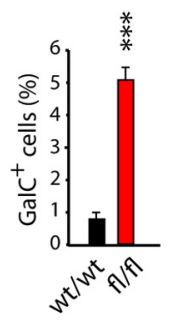

Figure 3. TACE deficiency in OPs induces premature cell cycle exit during postnatal SCWM development. $\boldsymbol{A}, \boldsymbol{F}, \boldsymbol{K}, \boldsymbol{N}$, Time line depicts the TAM (red bar) treatment paradigm and time points of analysis (arrows). TAM was injected into control PDGFR $\alpha$-Cre ${ }^{\mathrm{tm}}:$ TACE $^{\mathrm{w} / \mathrm{w}} / \mathrm{YFP}(\mathrm{w} / \mathrm{w})$ and PDGFR $\alpha$ - $-\mathrm{re}^{\mathrm{tm}}{ }^{\text {:TACE }}{ }^{\mathrm{fl} / \mathrm{fl}} / \mathrm{YFP}$ (fl/fl) mice $(3$ times, $24 \mathrm{~h}$ apart) starting at P6, and tissue was processed at the indicated time points (P9 and P15). $\boldsymbol{B}-\boldsymbol{E}$, Representative confocal images and quantification of total $\mathrm{YFP}^{+}$cells $(\boldsymbol{B}, \boldsymbol{C})$ and $\mathrm{CC} 1^{+} 0 \mathrm{Ls}(\boldsymbol{D}, \boldsymbol{E})$ cells in the SCWM at 1 week after TAM (P15). YFP ${ }^{+}$and $\mathrm{CC}^{+}$cell numbers were significantly reduced in the SCWM of fl/fl mice compared with control mice. $\boldsymbol{F}-J$, Immunofluorescence analysis and quantification of the percentage of proliferating OPs $\left.\left(\mathrm{BrdU}^{+} \mathrm{NG2}{ }^{+} \mathrm{YFP}^{+} / \mathrm{YFP}^{+} ; \boldsymbol{G}, \boldsymbol{H}\right), \mathrm{OPs}_{(\mathrm{NG2}}{ }^{+} \mathrm{YFP}^{+} / \mathrm{YFP}^{+} ; \boldsymbol{I}, \boldsymbol{J}\right)$, and pre-0 $\mathrm{Os}\left(\mathrm{YFP}^{+} \mathrm{CC} 1^{+} ; \boldsymbol{I}, \boldsymbol{J}\right)$ within the YFP ${ }^{+}$recombinant population in the SCWM at 1 week after TAM (P15). $\boldsymbol{K}-\boldsymbol{M}$, Analysis of OP cell cycle exit in the developing SCWM. BrdU was injected at P6 and $3 \mathrm{~h}$ later mice received TAM injections for 2 consecutive days, and tissue was analyzed at $24 \mathrm{~h}$ after the last TAM injection. Representative images and quantifications of the percentage of OPs that remain in the cell cycle $\left(\mathrm{Ki}_{67}{ }^{+} \mathrm{BrdU}^{+} / \mathrm{BrdU}^{+}\right.$cells) in wt and $\mathrm{fl} / \mathrm{fl}$ mice in $\mathrm{fl} / \mathrm{fl} \mathrm{SCWM}$ at P8. TACE depletion in OPs accelerates cell cycle exit, as shown by the reduced percentage of Ki67 ${ }^{+} \mathrm{BrdU}^{+} / \mathrm{BrdU}^{+}$cells.

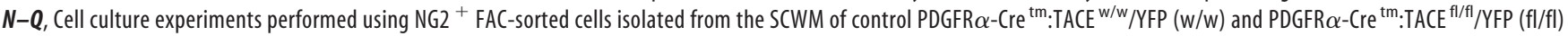
mice at $48 \mathrm{~h}$ after the last TAM injection (P6-P8). Representative images and quantification of the percentage of proliferating $0 \mathrm{Ps}$ (PDGFR $\alpha^{+} \mathrm{BrdU}^{+/} \mathrm{PDGFR} \alpha^{+}$cells; $\left.\mathbf{0}, \mathbf{P}\right)$ and pre-0L $\left(\mathrm{GalC}^{+} /\right.$total cells; $\left.\mathbf{Q}\right)$ at $48 \mathrm{~h}$ after plating. Data are shown as mean $\pm \mathrm{SEM} ; n=6-10$ brains for each time point and three independent experiments. Scale bars: $10 \mu \mathrm{m} .{ }^{* *} p<0.01$ and ${ }^{* * *} p<0.001$ versus control/control cells.

compared with control littermates (Fig. 3B-E), suggesting that TACE may regulate OP cell proliferation and/or OL lineage cell survival.

As expansion of OPs is an important stage during oligodendrogenesis and CNS myelination, we analyzed whether the defects in myelination observed in $\mathrm{fl} / \mathrm{fl}$ mice could be a consequence of a reduced proliferative capacity of fl/fl OPs. To this end, we first induced TACE deletion at P6-P8 and we analyzed OP proliferation in the SCWM of wt and fl/fl mice at $24 \mathrm{~h}$ (P9) and 1 week (P15) after the last TAM administration. BrdU was administered to wt and $\mathrm{fl} / \mathrm{fl}$ mice $2 \mathrm{~h}$ before the end of the experiment (Fig. $3 F$ ). By using this paradigm, we detected a reduced number of proliferating $\mathrm{OPs}\left(\mathrm{BrdU}^{+}\right)$among the recombinant $\mathrm{YFP}^{+}$population, and a reduced density of proliferating $\mathrm{OPs}\left(\mathrm{NG}_{2}{ }^{+} \mathrm{BrdU}^{+}\right)$in the SCWM of fl/fl mice (Fig. 3G,H; data not shown). Consistent with this observation, immunofluorescence analysis revealed a reduced percentage of $\mathrm{NG}^{+}$cells (OPs) and increased percentage of OLs $\left(\mathrm{CCl}^{+}\right)$within the recombinant $\mathrm{YFP}^{+}$population in the SCWM of fl/fl mice at both developmental stages (P9 and P15) compared with their wt littermates (Fig. $3 I, J$ ), suggesting that TACE depletion in OPs induces premature cell cycle exit and OL differentiation. To fully examine the cell cycle dynamics in OPs after TACE deletion, we performed cell cycle exit experiments in vivo. Control and $\mathrm{fl} / \mathrm{fl}$ mice were injected with BrdU at $\mathrm{P} 6$ and $3 \mathrm{~h}$ later, and mice received two TAM injections $(24 \mathrm{~h}$ apart). We analyzed OP cell cycle exit by using Ki67 and BrdU labeling at $24 \mathrm{~h}$ after the last TAM (Fig. $3 \mathrm{~K}$ ). We quantified the proportion of double-labeled $\mathrm{BrdU}{ }^{+} \mathrm{Ki}_{67}{ }^{+}$cells (as Ki67 is an endogenous marker of cycling OPs) over BrdU-labeled cells (in S phase) in the developing SCWM of control and $\mathrm{fl} / \mathrm{fl}$ mice. TACE depletion in OPs induced premature cell cycle exit, as a reduced proportion of cycling $\mathrm{Ki}_{67}{ }^{+} \mathrm{BrdU}^{+} \mathrm{OPs}$ was found in the SCWM of fl/fl mice compared with control mice (Fig. $3 L, M)$. 
To confirm these findings, we performed OP cell culture experiments. Control and PDGFR $\alpha-\mathrm{Cre}^{\mathrm{tm}}: \mathrm{TACE}^{\mathrm{fl} / \mathrm{fl}}:$ YFP mice received TAM at $\mathrm{P} 6$ for 3 consecutive days and $24 \mathrm{~h}$ after last TAM injection, and the SCWM of control and $\mathrm{fl} / \mathrm{fl}$ mice was dissected out and prepared for FAC-sorting (Fig. 3N). Isolated $\mathrm{NG} 2{ }^{+} \mathrm{YFP}^{+} \mathrm{OPs}$ were cultured under proliferative culture conditions and $48 \mathrm{~h}$ later were processed for analysis. As observed in vivo, TACE depletion in OPs induced OP cell cycle withdrawal, as we found reduced numbers of proliferating $\mathrm{OPs}\left(\mathrm{BrdU}^{+} /\right.$ PDGFR $\alpha^{+}$) in fl/fl OP cultures compared with control OP cultures (Fig. 3O,P). Moreover, at the same time point and under the same culture conditions, we detected a higher number of pre-OLs $\left(\mathrm{GalC}^{+}\right.$cells; Fig. 3Q) in fl/fl cultures, confirming our results in vivo and suggesting that TACE deletion in OPs induces premature cell cycle withdrawal and differentiation. Altogether, our analysis here demonstrates that TACE is essential for determining the proper timing of OP cell cycle exit to accurate OL development and functional CNS myelination.

\section{TACE/ADAM17 supports OL lineage cell survival}

To define if the reduced number of OL lineage cells observed in fl/fl SCWM could be a result of altered cell survival, we analyzed Caspase $3^{+}$expression within the recombinant $\mathrm{YFP}^{+}$population in the SCWM of wt and $\mathrm{fl} / \mathrm{fl}$ mice. Immunofluorescence analysis at $24 \mathrm{~h}$ after last TAM injection (P9, Tam P6-P8) evidenced an increased number of $\mathrm{YFP}^{+} /$Caspase $^{+}$cells in the SCWM of fl/fl mice (Fig. $4 A-C$ ). Our data indicate that TACE deletion disturbs the survival of premyelinating $\mathrm{OLs}\left(\mathrm{YFP}^{+} \mathrm{CCl}^{+}\right.$cells), as significantly more $\mathrm{YFP}^{+} \mathrm{CCl}^{+}$Caspase $3^{+}$cells were found in the SCWM of fl/fl mice. We also observed increased cell death among OPs $\left(\mathrm{YFP}^{+} \mathrm{PDGFR} \alpha{ }^{+}\right.$Caspase $3^{+}$cells $)$at this time point, but to a lesser extent (Fig. $4 B, C$ ). These results were confirmed by WB analysis, as we found increased activated-Caspase 3 levels in the SCWM of fl/fl mice at P9, compared with control mice (Fig. 4D). Accordingly, fl/fl mice showed increased microglial activation (Iba- ${ }^{+}$cells) in the SCWM at this age (Fig. 4E,F). Phagocytosis of OL lineage cells by microglia occurred frequently in the developing fl/fl SCWM (Fig. 4G,H), supporting the idea that the reduction in OL lineage cell number observed in the SCWM of fl/fl mice is a consequence of increased OL lineage cell death during SCWM myelination.

We further confirmed the role of TACE on OL lineage cell survival by using $\mathrm{OP}$ cell culture experiments as above. FACsorted control and fl/fl OPs $\left(\mathrm{NG}_{2}{ }^{+} \mathrm{YFP}^{+}\right)$were obtained from the SCWM of control and PDGFR $\alpha-\mathrm{Cre}^{\mathrm{tm}}$ :TACE ${ }^{\mathrm{fl} / \mathrm{fl}}$ :YFP mice and cultured for $24 \mathrm{~h}$ or $48 \mathrm{~h}$ under proliferative conditions (Fig. $4 I)$. Immunofluorescence analysis evidenced an increased number of Caspase $3^{+} \mathrm{PDGFR} \alpha^{+}$cells in $\mathrm{fl} / \mathrm{fl}$ cultures compared with controls at both time points (Fig. $4 J, K$ ). Moreover, in $\mathrm{fl} / \mathrm{fl} \mathrm{cul-}$ tures, we also found an increased proportion of Caspase $3^{+}$cells among the pre-OL population $\left(\mathrm{CNP}^{+}\right.$and $\mathrm{GalC}^{+}$cells), confirming the results observed in vivo (Fig. $4 K$ ). Our data here demonstrate that TACE is essential for determining the proper timing of OP expansion and cell cycle exit and for sustaining OL lineage cell survival during the critical periods of oligodendrogenesis and SCWM myelination.

\section{TACE/ADAM17 is essential for EGFR activation in} oligodendroglial lineage cells during postnatal myelination TACE has been proposed as the main ADAM metalloproteinase responsible for the shedding of EGFR ligands in several developmental and pathological contexts (Sahin et al., 2004; Blobel, 2005; Scheller et al., 2011). Moreover, EGFR is an important modulator of OL development, specifically by supporting the survival, expansion, and migration of the pool of OPs in the subventricular zone and OL migration during OL regeneration after demyelination (Aguirre and Gallo, 2007; Aguirre et al., 2007). To analyze whether TACE acts via EGFR in OL lineage cells during postnatal myelination, we analyzed EGFR activation in OL lineage cells in the SCWM of wt and $\mathrm{fl} / \mathrm{fl}$ mice. Control and $\mathrm{fl} / \mathrm{fl}$ mice received TAM at P6 for 3 consecutive days and EGFR activation was analyzed in OL lineage cells in the SCWM at $24 \mathrm{~h}$ after the last TAM injection. Immunofluorescence analysis revealed reduced EGFR activation levels in $\mathrm{fl} / \mathrm{fl} \mathrm{YFP}^{+} \mathrm{OL}$ lineage cells compared with control $\mathrm{YFP}^{+}$cells (Fig. 5A). Moreover, WB analysis confirmed reduced EGFR activation levels in the SCWM of fl/fl mice (Fig. $5 C, D)$ These findings suggest a crucial role for TACE in modulating EGFR activation in OL lineage cells during postnatal SCWM myelination.

Several studies have elegantly demonstrated that TACE depletion results in similar cellular and molecular alterations as to those observed in mice lacking EGFR ligands and/or receptors (Jackson et al., 2003; Sternlicht et al., 2005; Franzke et al., 2012). Hence, we investigated whether this phenotype also operates in the context of oligodendrogenesis and CNS myelination by analyzing SCWM development of the EGFR hypomorphic mouse line (Wa2). Immunohistochemistry and WB analysis revealed similar reduced levels of pEGFR in the SCWM of P15 Wa2 and PDGFR $\alpha$-cre:TACE ${ }^{\mathrm{fl} / \mathrm{fl}}$ mice compared with their respective control littermates (Fig. 5A-F). WB and immunofluorescence analysis of myelin proteins at P15 in the SCWM showed similar alterations in postnatal myelination in the Wa2 and NG2cre:TACE ${ }^{\mathrm{fl} / \mathrm{fl}}$ mouse lines (Fig. $5 E-G$ ). Interestingly, we also detected similar alterations in motor functions in $\mathrm{Wa} 2$ and NG2-cre:TACE ${ }^{\mathrm{fl} / \mathrm{fl}}$ mice at P30 using the Open Field apparatus (Fig. $5 H-J$ ). Our data suggest the involvement of TACE in EGFR signaling activation in OL lineage cells during oligodendrogenesis and postnatal SCWM myelination.

\section{TACE/ADAM17 is crucial for TGF $\alpha$ and HB-EGF shedding in OL lineage cells during postnatal myelination}

The relevance of EGFR signaling during postnatal CNS myelination and remyelination after demyelination has been recently demonstrated (Aguirre et al., 2007; Scafidi et al., 2014). However, the source of EGFR ligands that drives OP expansion, OL development, and regeneration during myelination and remyelination has never been addressed. We hypothesized that OL lineage cells represent an important source of EGFR ligands during CNS myelination, where shedding is mainly modulated by TACE. To address this, we first characterized the pattern of HB-EGF shedding during SCWM development. WB analysis of total protein extracts isolated from the SCWM at different postnatal ages revealed a similar pattern between TACE expression and HB-EGF shedding during postnatal SCWM development (Figs. 6A, 1A,B), suggesting a functional interaction between TACE, EGFR signaling, and SCWM myelination. Immunofluorescence analysis in the SCWM of CNP-EGFP mice revealed high expression levels of HB-EGF in OL lineage cells (Fig. 6B). Furthermore, to confirm the expression of EGFR ligands by OL lineage cells, we analyzed the expression levels of EGFR ligands from FAC-sorted CNP$\mathrm{EGFP}^{\text {low }}$ (OPs) and CNP-EGFP ${ }^{\text {high }}$ (pre-OLs) as above. Transcripts from both EGFR ligands HB-EGF and TGF $\alpha$ were detected in OPs and pre-OL extracts (Fig. 6C,D). Our data here suggest that the mechanism by which TACE regulates OL development, including cell survival and proliferation, could be mediated by modulating the shedding of HB-EGF and 
A

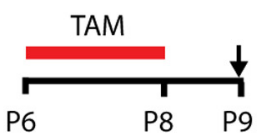

E

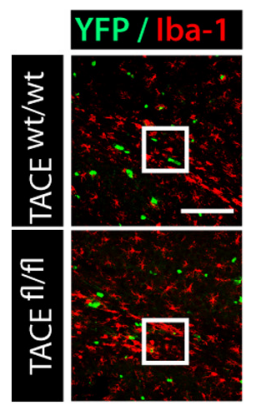

B

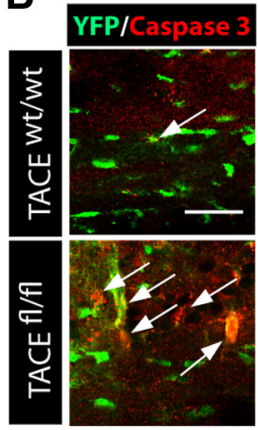

F

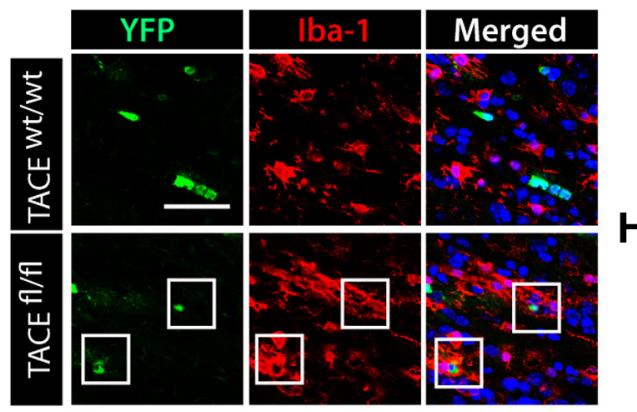

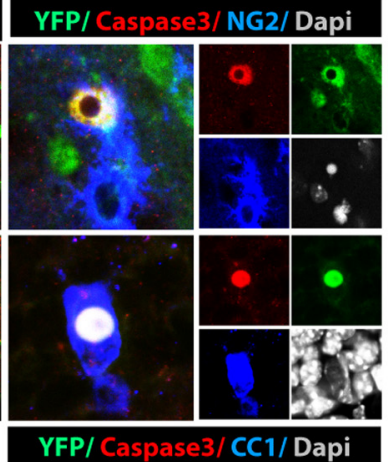

C

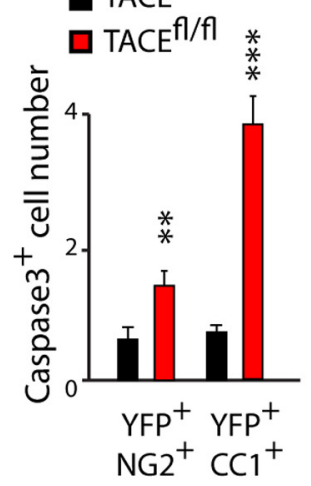

D

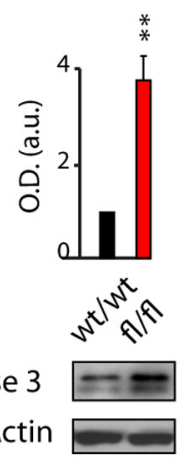

G

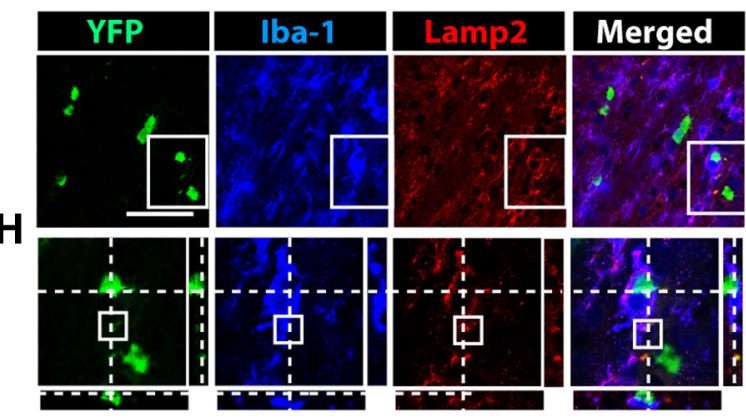

I

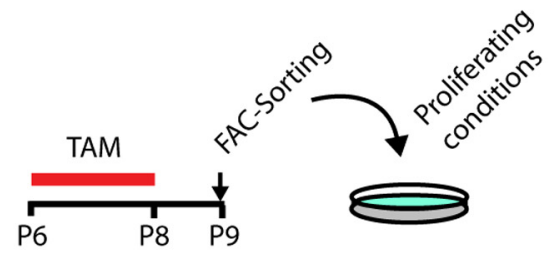

J

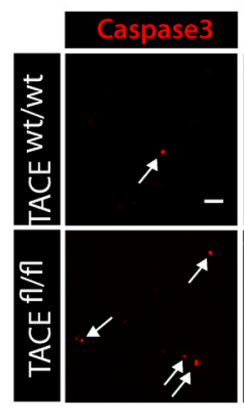

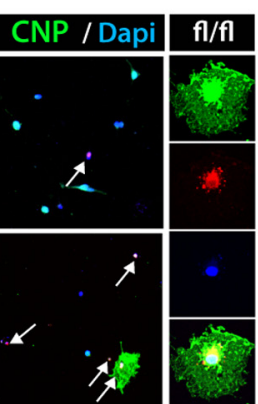

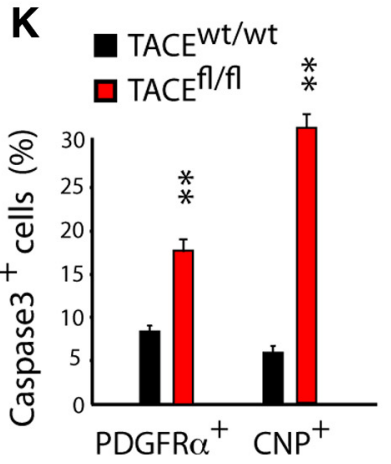

Figure 4. TACE deficiency in OPs disturbs $\mathrm{OL}$ lineage cells survival. $A-G$, Characterization of $0 \mathrm{~L}$ lineage cell death in the SCWM of the control PDGFR $\alpha$-Cre ${ }^{\mathrm{tm}}: \mathrm{TACE}{ }^{\mathrm{w} / \mathrm{w}} / \mathrm{YFP}(\mathrm{w} / \mathrm{w})$ and

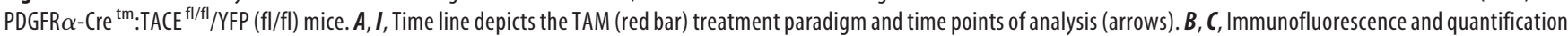
of $0 \mathrm{~L}$ lineage cell death by detecting activated caspase $3\left(\right.$ Caspase $^{+}{ }^{+}$) cells in the SCWM at $24 \mathrm{~h}$ after the last TAM (P9). Increased numbers of activated Caspase ${ }^{+}$cells within $0 \mathrm{Ps}$ $\left(\mathrm{YFP}^{+} \mathrm{NG2}{ }^{+}\right.$cells) and pre-OL $\left(\mathrm{YFP}^{+} \mathrm{CC}^{+}\right)$cell populations were observed in $\mathrm{fl} / \mathrm{fl} \mathrm{SCWM} \mathrm{compared} \mathrm{with} \mathrm{control.} \boldsymbol{D}$, SCWM of control and fl/fl mice at P9 was dissected and tissue was prepared for WB analysis. Representative blot for active Caspase3 obtained from fl/fl and control SCWM protein extracts. Histograms are expressed as arbitrary units (a.u.) after actin normalization. $\boldsymbol{E}$, Anti-lba 1 antibodies were used to detect microglial cells at $24 \mathrm{~h}$ after the last TAM administration (P9). Analysis of the SCWM of fl/fl mice showed increased microglial activation (Iba- $1^{+}$) compared with wt mice. $\boldsymbol{F}-\boldsymbol{H}$, Also at this time point, increased numbers of YFP ${ }^{+} \mathrm{OL}$ lineage cells had been phagocytized by microglial cells in the fl/fl $\mathbf{S C W M} \mathbf{G}, \boldsymbol{H}$, Immunofluorescence with anti-Lamp2 ${ }^{+}$antibodies was performed to detect phagocytosis in the SCWM of the fl/fl and control mice. Representative confocal images depicting examples of YFP ${ }^{+}$cells in the process of being phagocytized by microglial cells, in which YFP protein is being degraded inside microglial lysosomes (Lamp2 ${ }^{+}$). $\boldsymbol{H}$, Confocal images show orthogonal planes of the squared area in $\boldsymbol{G}$. $\boldsymbol{I}-\boldsymbol{K}$, Cell culture experiments performed with NG2 ${ }^{+}$FAC-sorted cells isolated from the SCWM of PDGFR $\alpha$-Cre ${ }^{\mathrm{tm}}:$ TACE ${ }^{\mathrm{w} / \mathrm{w}} / \mathrm{YFP}$ (control) and PDGFR $\alpha$ -

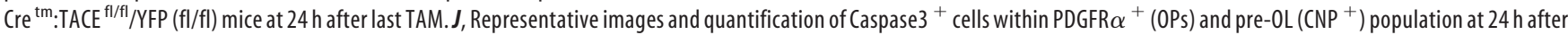
plating. Analysis shows that TACE depletion in OPs reduces cell survival, as higher numbers of Caspase $3^{+} \mathrm{OL}$ lineage cells were found in $\mathrm{fl} / \mathrm{fl}$ cultures. Right, Shows an example of a pre- $0 \mathrm{~L}$ in the process of apoptosis $\left(\mathrm{CNP}^{+}\right.$Capase $\left.3^{+}\right)$, which is more abundant in fl/fl OP cultures. Cell numbers are expressed as the percentages of Caspase $3^{+}$cells within NG2 ${ }^{+}(\mathrm{OPs})$ or CNP ${ }^{+}$ (OLs) cells. Data are shown as mean $\pm \mathrm{SEM} ; n=6-10$ brains for each time point and three independent experiments Scale bars: $10 \mu \mathrm{m} .{ }^{* *} p<0.01$ and ${ }^{* * *} p<0.001$ versus control (w/w) cells.

TGF $\alpha$, and, consequently, the activation of EGFR signaling in OL lineage cells. To determine whether TACE controls EGFR ligand shedding in OL lineage cells during postnatal myelination, we analyzed HB-EGF and TGF $\alpha$ shedding in the developing SCWM of wt and $\mathrm{fl} / \mathrm{fl}$ mice. Control and $\mathrm{fl} / \mathrm{fl}$ mice received TAM injections for 3 consecutive days (P6-P8) and SCWM extracts were obtained at $48 \mathrm{~h}$ after the last TAM in- jection (Fig. 6E). By using this approach, our WB analysis evidenced reduced shedding of HB-EGF and TGF $\alpha$ in the SCWM of fl/fl mice (Fig. $6 F, G$ ), suggesting a role for TACE in modulating EGFR ligand shedding in OL lineage cells during SCWM development.

Stimulated ectodomain shedding by phorbol esters (PMA) is considered a critical feature of ADAM proteins, and 
A

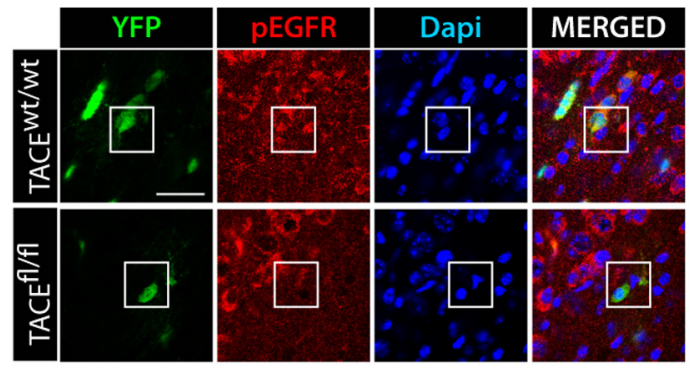

B

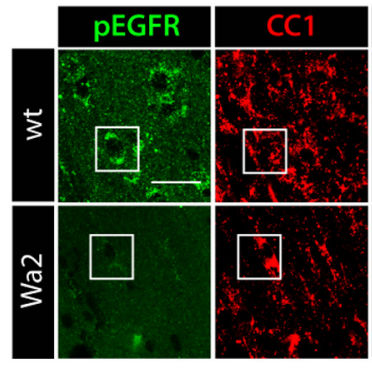

G

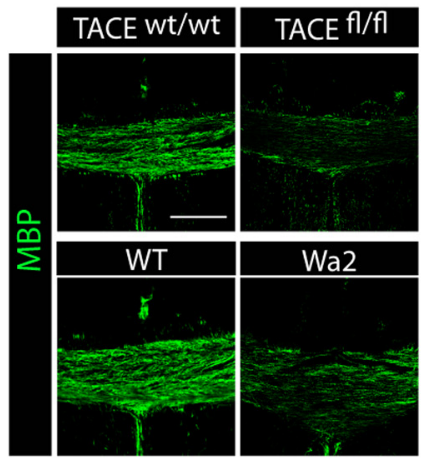

C

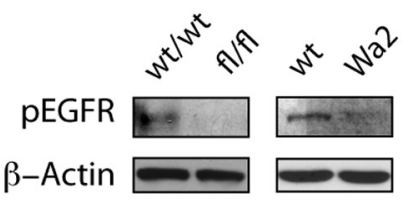

E

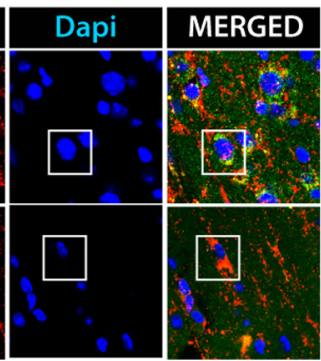

D

$\square$ PDGFR $\alpha$-cre::TACE ${ }^{\text {fl/f }}$ vs wt

Wa2 vs wt

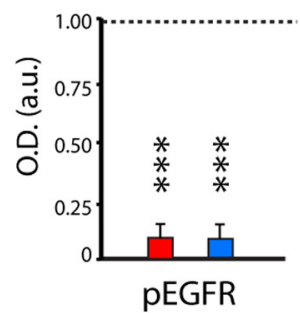

$\mathbf{F}$

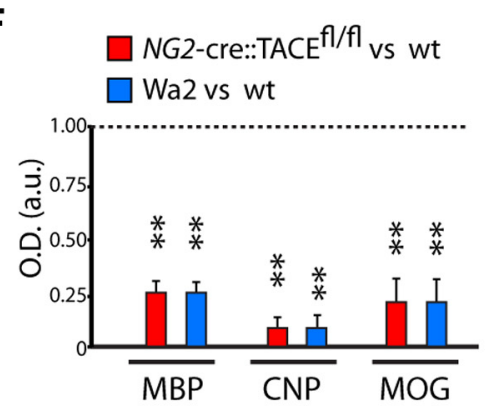

J

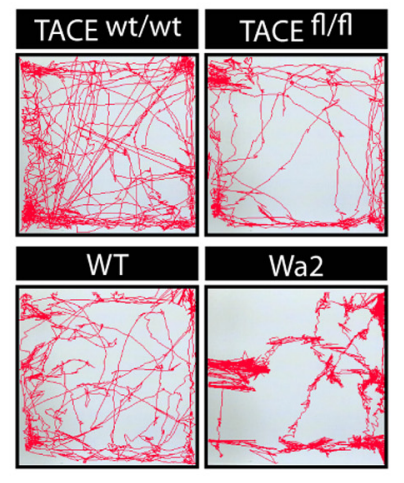

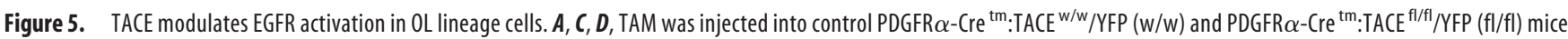
(2 times, $24 \mathrm{~h}$ apart) starting at P6, and tissue was processed at 1 week after last the TAM injection (P15). $A$, Characterization of the EGFR activation levels in 0L lineage cells in the SCWM. Reduced $p E G F R$ levels in recombinant YFP ${ }^{+}$cells were observed in $\mathrm{fl} / \mathrm{fl}$ samples compared with control samples. $\boldsymbol{B}, A$ similar reduction in pEGFR levels within $0 \mathrm{Ls}$ was 0 bserved in the

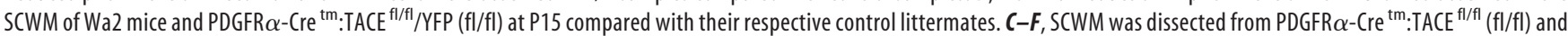
Wa2 mice at P15 to analyze EGFR activation levels by WB analysis. G, Representative confocal images in the SCWM at P15 of myelin proteins in the NG2-Cre::TACE fl/fl and Wa2 mice. Histograms express results in arbitrary units (a.u.) after actin normalization and referred to the levels of their corresponding wt littermates. $H$-J, Locomotor activity of NG2-Cre::TACE fl/fl, Wa2, and their respective control mice was evaluated at P30 by using the Open Field apparatus. $\boldsymbol{H}$, Velocity is measured as the mean velocity in a $10 \mathrm{~min}$ test trial. $\boldsymbol{I}$, Time spent in fast movement, defined as time spent performing movements faster than $4 \mathrm{~cm} / \mathrm{s}$.J, Representative patterns of locomotor activity in the Open Field Test of NG2-Cre::TACE fl/ffl, Wa2, and control mice from each genotype time at P30. Data are shown as mean $\pm \mathrm{SEM} ; n=6-12$ brains for each time point and three independent experiments. Scale bars: $\boldsymbol{A}, \boldsymbol{B}, 5 \mu \mathrm{m} ; \boldsymbol{G}, 100 \mu \mathrm{m}$. ${ }^{*} p<0.05,{ }^{* *} p<0.01$, and ${ }^{* *} p<0.001$ versus control of each phenotype.

ADAM17 has been proposed as the major PMA-responsive sheddase (Blobel, 2005, Horiuchi et al., 2007, Kveiborg et al., 2011). Thus, to directly address whether TACE modulates EGFR ligand shedding in OL lineage cells, we studied the capacity of $\mathrm{fl} / \mathrm{fl}$ OL lineage cells to respond to PMA stimulation, both in vitro and in vivo. First, FAC-sorted OPs obtained from the SCWM of control and $\mathrm{fl} / \mathrm{fl}$ mice were stimulated with PMA, and 4 h later, HB-EGF shedding was analyzed by quantifying the levels of the mature form in the culture media by ELISA (Fig. 6H). Our data showed that PMA induced HB-EGF shedding and release in wt OP cell cultures. In parallel, fl/fl OP cultures showed reduced HB-EGF shedding compared with wt control OP cultures, and similar levels of HB-EGF were found in the supernatant of vehicle and PMA-stimulated fl/fl OP cultures (Fig. 6I), suggesting that TACE is the main ADAM protein responsible for the shedding and release of the mature form of this EGFR ligand in OL lineage cells.

To examine whether HB-EGF shedding is also mediated by TACE in OL lineage cells in vivo, we administered PMA into control and PDGFR $\alpha-\mathrm{Cre}^{\mathrm{tm}}: \mathrm{TACE}^{\mathrm{fl} / \mathrm{fl}}$ mice. Both, control and $\mathrm{fl} / \mathrm{fl}$ mice received TAM injections (P6-P8), and $24 \mathrm{~h}$ later mice received a single PMA injection, and $4 \mathrm{~h}$ later SCWM tissue was processed to analyze EGFR ligand shedding by WB analysis (Fig. $6 J)$. Interestingly, PMA administration in vivo induced HB-EGF and TGF $\alpha$ shedding in control mice, as higher levels of the mature forms were found in the SCWM of PMA-induced control 
A

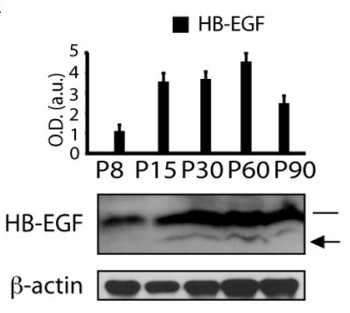

B

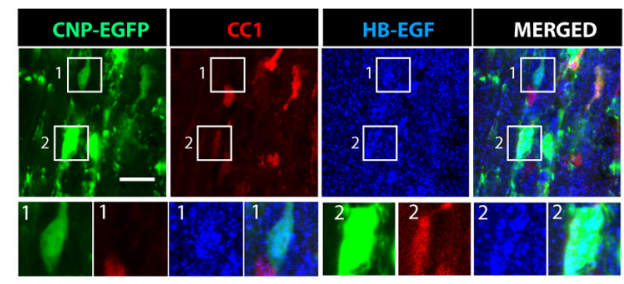

C

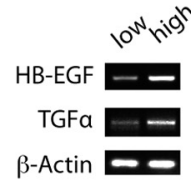

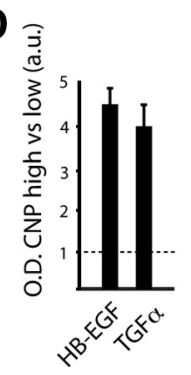

E

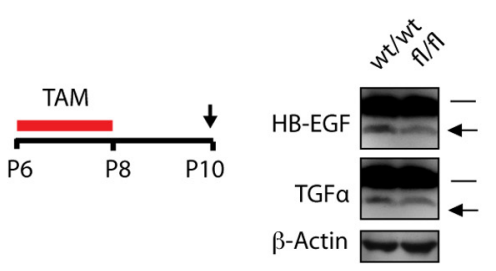

G

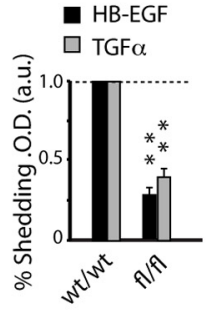

H

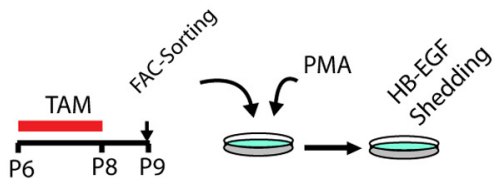

I

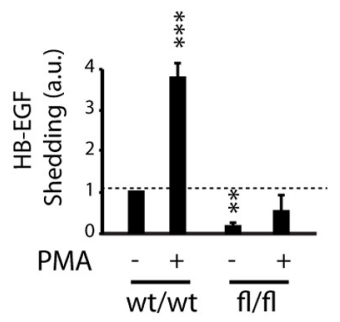

J

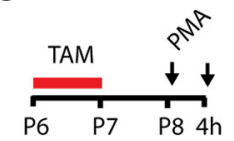

K

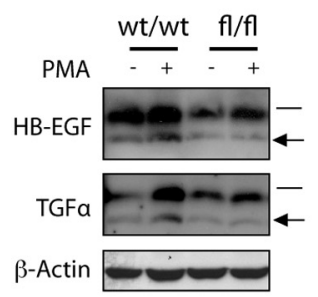

L

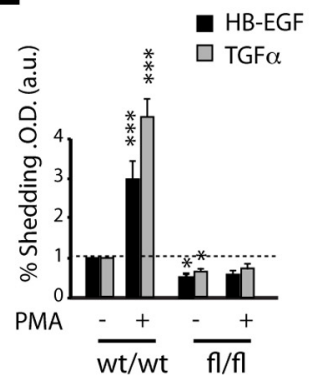

M

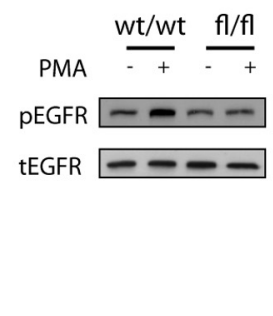

N

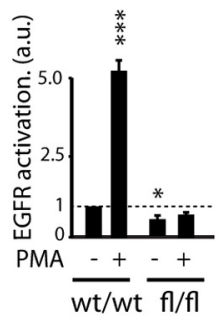

Figure 6. TACE is essential for EGFR ligand shedding and EGFR signaling activation in OL lineage cells. A, WB analysis and quantification of HB-EGF shedding from SCWM protein extracts obtained at P8 -P90. This analysis suggests a relation between TACE expression (Fig. 1A), EGFR ligand shedding, and SCWM myelination. Arrows in $\boldsymbol{F}$ and $\boldsymbol{K}$ represents the mature form of HB-EGF. Note that the same blot from Figure $1 A$ was reincubated with anti-HB-EGF, and as such, is presented with the same loading control. $B$, Characterization by immunofluorescence analysis of HB-EGF expression in OL lineage cells during SCWM development. Immunofluorescence with anti-HB-EGF and anti-CC1 antibodies at P15 in the SCWM of CNP-EGFP mice. HB-EGF expression was observed in OPS (CNP-EGFP $\left.{ }^{\text {low }} \mathrm{CC} 1^{\text {neg }} ; 1\right)$ and cell undergoing OL differentiation (CNP-EGFP hight $C\left(1^{+} ; 2\right)$. C, D, CNP-EGFP ${ }^{+}$cells were isolated from SCWM of the CNP-EGFP mouse at P4. RT-PCR analysis and quantification of HB-EGF and TGF $\alpha$ mRNA levels from CNP-EGFP low (OPs) and CNP-EGFP high (OLs) FAC-sorted cells. E, J, Time line depicts the TAM (red bar) and PMA administration paradigm and time points of analysis (arrows). TAM was injected into control PDGFR $\alpha$-Cre ${ }^{\text {tm }: T A C E ~}{ }^{\mathrm{w} / \mathrm{w}}$ (w/w) and PDGFR $\alpha$-Cre ${ }^{\text {tm: }}: \mathrm{TACE}^{\mathrm{fl} / \mathrm{fl}}$ (fl/fl) mice (2 or 3 times, $24 \mathrm{~h}$ apart) starting at P6.F, G, WB analysis of SCWM extracts to detect EGFR ligand (HB-EGF and TGF $\alpha$ ) shedding in the SCWM of wt and fl/fl mice at $48 \mathrm{~h}$ after the last TAM injection. $\boldsymbol{H}, \boldsymbol{I}, \mathrm{NG2}{ }^{+}$cells (OPS) were FAC-sorted from the SCWM of P8 control and fl/fl mice and cultured under proliferative conditions. At $24 \mathrm{~h}$ after plating, cells were stimulated with either PMA or vehicle for $4 \mathrm{~h}$ and subsequently supernatant was collected to detect the mature form of HB-EGF by ELISA. Results are expressed as arbitrary units (a.u). J-N, PMA was administered as illustrated in $\boldsymbol{J}$ and tissue was processed to detect EGFR ligand shedding $(\boldsymbol{K}, \boldsymbol{L})$ and pEGFR levels $(\boldsymbol{M}, \boldsymbol{N})$ by WB analysis. $\boldsymbol{K}, \boldsymbol{L}$, Bars and arrows point to the immature and mature forms, respectively, of HB-EGF and TGF $\alpha$. Data were calculated as the ratio of the respective cleaved and uncleaved forms of HB-EGF or TGF $\alpha$ and referred to actin levels. Results are expressed as percentage of shedding in arbitrary units (a.u.). $\boldsymbol{M}, \boldsymbol{N}$, EGFR activation levels were calculated as the ratio of $p E G F R /$ total-EGFR(tEGFR) levels and expressed in arbitrary units (a.u.). Data are shown as mean \pm SEM; $n=6-10$ brains for each time point and three independent experiments Scale bars: $5 \mu$ m. ${ }^{* *} p<0.01$ and ${ }^{* * *} p<0.001$ vs control mice.

mice compared with vehicle-treated control mice (Fig. $6 K, L$ ). However, PMA failed to modulate EGFR ligand shedding in the SCWM of $\mathrm{fl} / \mathrm{fl}$ mice. Moreover, WB analysis of extracts from the SCWM of control and fl/fl mice obtained at $4 \mathrm{~h}$ after PMA administration confirmed the involvement of TACE in OL lineage EGFR activation, as we found increased pEGFR levels in the SCWM of PMA-treated control mice compared with vehicletreated wt mice (Fig. $6 M, N$ ). In contrast, fl/fl SCWM extracts showed reduced pEGFR levels compared with control mice, and similar EGFR activation levels were found in SCWM of PMA and vehicle-treated fl/fl mice (Fig. $6 \mathrm{M}, N$ ). Our data here identify $\mathrm{OL}$ lineage cells as a source of EGFR ligands during SCWM development and implicate TACE as the main ADAM protein responsible for EGFR ligand shedding and EGFR activation in OL lineage cells during SCWM myelination.
EGFR overexpression rescues the deficits in oligodendrogenesis of TACE-deficient OPs

To further support the hypothesis that TACE promotes OP cell proliferation and survival through EGFR signaling, we performed gain-of-function experiments in vitro by using a retrovirus-based strategy to drive forced EGFR overexpression and subsequent activation (Aguirre et al., 2005, 2007). For this purpose, control and fl/fl OP cultures obtained by FAC-sorting as above were infected with EGFR overexpressing or control retrovirus that also expresses the GFP protein under the control of the CMV promoter. Transduced cell cultures were processed at $24 \mathrm{~h}$ and $3 \mathrm{~d}$ by immunocytochemistry to analyze cell proliferation, survival, and development. Consistent with previous reports (Ivkovic et al., 2008), immunofluorescence analysis evidenced increased EGFR activation levels in EGFR overexpressing OPs, 
A
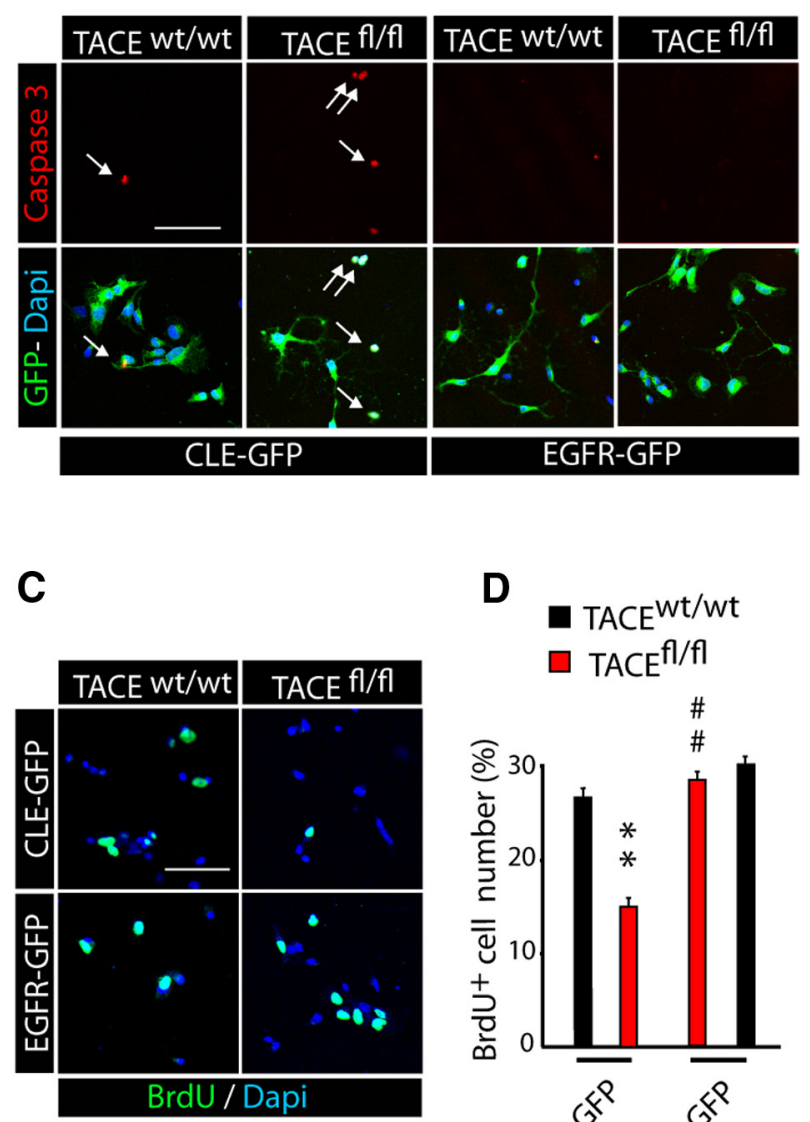

B

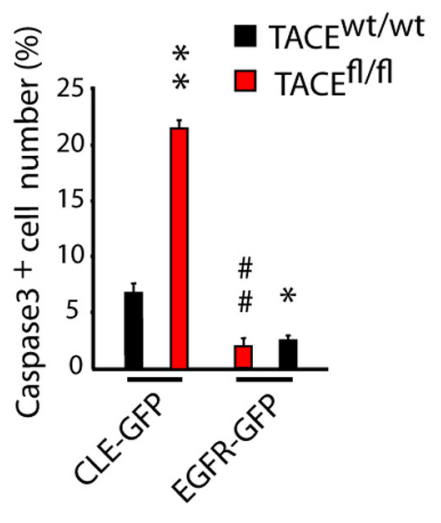

E

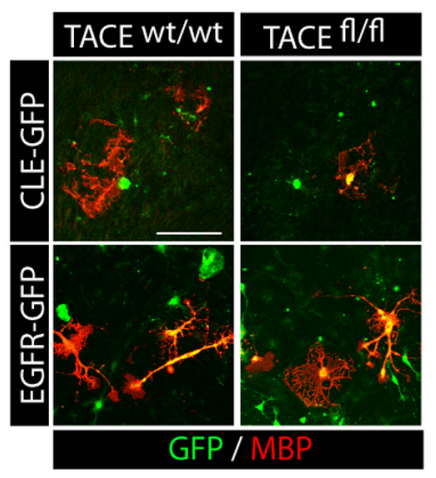

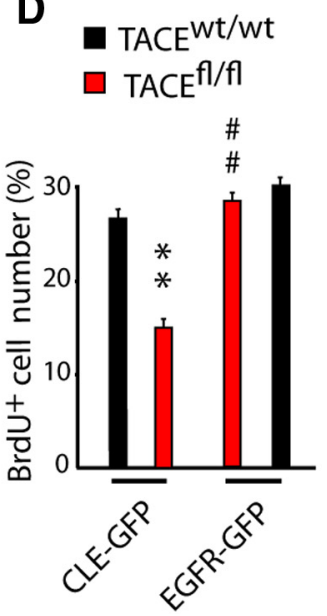

$\mathbf{F}$

- TACE ${ }^{\mathrm{Wt}} / \mathrm{wt}$

$\square T A C E^{f l / f l}$

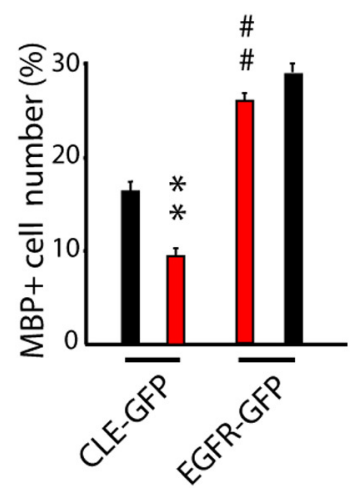

Figure 7. EGFR overexpression in TACE-deficient OPs rescues $0 \mathrm{~L}$ survival and development. Cell culture experiments using FAC-sorted YFP ${ }^{+}$cells (OPs). Cell were isolated from the SCWM of control PDGFR $\alpha-\mathrm{Cre}^{\mathrm{tm}}:$ TACE $^{\mathrm{w} / \mathrm{w}}(\mathrm{w} / \mathrm{w})$ and PDGFR $\alpha$ - $\mathrm{Cre}^{\mathrm{tm}}: \mathrm{TACE}^{\mathrm{ff} / \mathrm{fl}}(\mathrm{fl} / \mathrm{fl})$ mice at $24 \mathrm{~h}$ after the last TAM injection. OPs were maintained under proliferative culture conditions and transduced with a retroviral construct that drives the expression of EGFR (EGFR-GFP) or just GFP alone (control;CLE-GFP). At $24 \mathrm{~h}$ after viral transduction cells were processed to analyze cell survival and cell proliferation by immunocytochemistry. $\boldsymbol{A}-\boldsymbol{D}$, Representative fluorescent images and quantification of Caspase ${ }^{+}(\boldsymbol{A}, \boldsymbol{B})$ and $\mathrm{BrdU}^{+}(\boldsymbol{C}, \boldsymbol{D})$ transduced cells at $24 \mathrm{~h}$ after viral infection. $\boldsymbol{E}, \boldsymbol{F}$, Representative immunofluorescence images and cell quantifications of $\mathrm{MBP}^{+} \mathrm{OLs}$ at $3 \mathrm{~d}$ after viral infection. Note that $\mathrm{EGFR}$ overexpression rescues the deficiencies in $\mathrm{OP}$ proliferation and $0 \mathrm{~L}$ lineage cell survival and allows $\mathrm{OL}$ lineage cells to continue their development into mature myelinating $0 \mathrm{Ls}$. Cell numbers are expressed as the percentages of positive cells within the EGFP ${ }^{+}$-infected cells. Scale bars: $10 \mu \mathrm{m} .{ }^{* *} p<0.01$ versus w/w CLE-GFP control cells and ${ }^{\# \#} p<0.01$ versus TACE ${ }^{\text {fl/fl }}$ CLE-GFP control cells.

both in control and $\mathrm{fl} / \mathrm{fl}$ cultures, compared with their respective controls (data not shown). Moreover, EGFR overexpression restored the deficits in cell viability and proliferation in fl/fl OPs, as a reduced number of Caspase $3^{+}$cells and higher numbers of $\mathrm{BrdU}^{+}$cells were observed in EGFR overexpressing fl/fl OP cultures compared with their controls (Fig. $7 A-D$ ). Furthermore, $\mathrm{fl} / \mathrm{fl}$ cultures were able to reach the mature phenotype when cultured under conditions of OL differentiation, as immunofluorescence analysis with anti-MBP antibodies showed a higher number of $\mathrm{MBP}^{+}$cells in $\mathrm{fl} / \mathrm{fl}$ cultures transduced with EGFR when compared with their controls (Fig. 7 E,F). Our data demonstrate for the first time the critical role of TACE in OL lineage cells during oligodendrogenesis and SCWM myelination, and suggest that TACE exerts an essential function in modulating EGFR ligand shedding and subsequent EGFR activation in OL lineage cells to sustain OP expansion and OL lineage cell survival during postnatal CNS myelination (Fig. 8).

\section{Discussion}

Ectodomain shedding of cell surface proteins by metalloproteinases generates many diverse bioactive cytokines and growth factors governing important cellular processes in the developing and adult organisms, including the control of growth, adhesion, and motility of cells (Yang et al., 2006; Edwards et al., 2008; Weber et al., 2012). Thus, their deregulation is also linked to pathological states, including cancer and nervous system diseases (Pruessmeyer and Ludwig, 2009). It is essential to understand the complex repertoire of physiological roles of these important and multifaceted molecules to design cellular strategies for promoting tissue repair. Our report shows for the first time that TACE, via EGFR ligand shedding, regulates the development of oligodendroglial cells during the critical periods of CNS myelination. Most of the studies that have addressed the relevance of EGFR signaling in oligodendrogenesis and CNS myelination examine this relationship either in the context of brain injury or analyzing its role on neural stem cells from the subventricular zone, but the role of EGFR signaling during oligodendrogenesis and CNS myelination is less clear (Aguirre and Gallo, 2007; Aguirre et al., 2007, 2010; Ivkovic et al., 2008; Gonzalez-Perez et al., 2009; Scafidi et al., 2014). Similarly, most of the reported functions of TACE are under pathological conditions, including inflammation, hypoxia, and cancer (Pruessmeyer and Ludwig, 2009; Weber and Saftig, 2012, Scheller et al., 2011). 
A

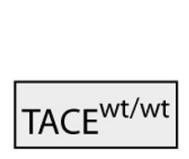

Proliferation

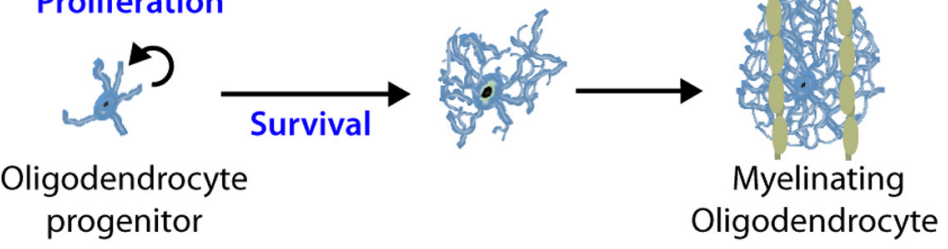

B

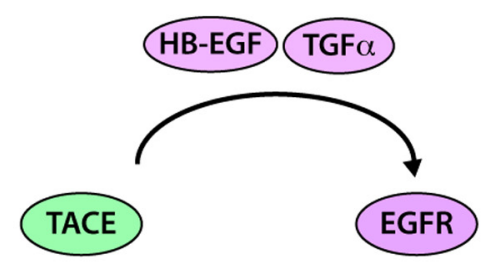

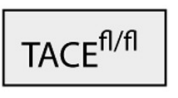
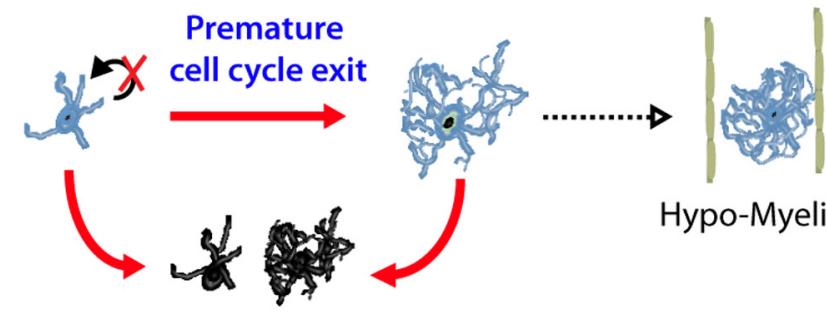

Hypo-Myelination

\section{Cell death}

Figure 8. Hypothetical model of how ADAM17 regulates OL development during postnatal SCWM myelination. $A$, TACE controls OP proliferation and survival in the developing SCWM. TACE depletion in OPs induces premature cell cycle exit and, as a consequence, $0 \mathrm{~L}$ lineage cell survival is compromised leading to hypomyelination in the SCWM. $\boldsymbol{B}$, Mechanistically, in $0 \mathrm{~L}$ lineage cells, ADAM17 modulates EGFR signaling activation by controlling EGFR ligand shedding (HB-EGF and TGF $\alpha$ ) during SCWM development.

Our study identifies for the first time TACE/ADAM17 as a novel key modulator of OL development during postnatal CNS myelination. TACE genetic depletion in OPs disturbs cell cycle maintenance and cell survival in OPs and premyelinating OLs. Strikingly, these cellular alterations in TACE fl/fl mice lead to deficits in postnatal SCWM myelination and motor behavior. As our data show that TACE depletion in OPs strongly impacts cell survival in OPs and premyelinating OLs, it is difficult to conclude if cell viability is also compromised in mature myelinating OLs. Further studies will be needed to define the cellular roles of TACE in mature myelinating $\mathrm{OL}$ and to further determine whether this molecule influences other stages of OL development. However, the high impact of TACE deletion in OPs on CNS myelination suggests that alterations in TACE functionality may be involved in the pathogenesis or progression of demyelinating disorders. Our data strongly suggest that TACE/ADAM17 promotes the expansion of OPs during the critical periods of SCWM myelination by modulating $\mathrm{OP}$ cell proliferation, but also by supporting OL lineage cell survival. While TACE depletion in OPs produces deficits in CNS myelination, TACE depletion in motor neurons accelerates PNS myelination, showing a divergence of TACE function between the CNS and PNS (La Marca et al., 2011). Thus, this study uncovers basic differences between OLs and Schwann cells and broadens our knowledge of the relationship and divergence between CNS and PNS development. However, on top of the presented functions of TACE in OL lineage cells, we cannot exclude that this molecule may also modulate CNS postnatal myelination in a noncell autonomous fashion.

By manipulating TACE expression, we elucidated that TACE represents an essential upstream modulator of EGFR signaling by promoting EGFR activation in OL lineage cells during CNS myelination. TACE genetic depletion abrogates EGFR ligand shedding and EGFR signaling activation in OL lineage cells and mimics the alterations in SCWM development observed in the hypofunctional EGFR mouse line Wa2. The fact that forced EGFR overexpression in $\mathrm{fl} / \mathrm{fl}$ OPs rescues their deficits in OL lineage cell survival, proliferation, and development further demonstrates that TACE acts via EGFR signaling during oligodendrogenesis to support postnatal CNS myelination. However, in the context of CNS development, TACE has been linked to the processing of substrates other than EGFR ligands, including Notch, N-CAM, ERB4, TrkA, and p75NTR. While, we do not assert that EGFR is the only mediator of TACE during oligodendrogenesis, the fact that the phenotype observed in $\mathrm{TACE}^{\mathrm{f} / \mathrm{fl}} \mathrm{OPs}$ was rescued by overexpressing EGFR suggests that EGFR signaling is one of the downstream targets of TACE in oligodendrogenesis during postnatal CNS myelination. Further studies will define whether TACE targets other substrates in OL lineage cells to modulate CNS myelination. As OL lineage cells express EGF ligands in the SCWM, we cannot discriminate if the release of EGFR ligands by OLs acts in an autocrine or a paracrine manner. Further experiments may be needed to address this important question. However, our PMA-stimulation experiments identify TACE as the primary ADAM protein responsible for HB-EGF and TGF $\alpha$ processing in OL lineage cells. Moreover our data suggest that OL lineage cells represent an important source of EGFR ligands during postnatal SCWM myelination.

Recent studies have pointed to EGFR as an essential signaling pathway for OL development during CNS myelination, but more importantly during OL regeneration and remyelination after demyelination (Aguirre and Gallo, 2007; Aguirre et al., 2007, 2010; Ivkovic et al., 2008). EGFR signaling is essential for OP expansion, migration, and OL regeneration after demyelination. Indeed, a recent report highlights the feasibility and potential clinical translation of manipulating EGFR signaling to promote oligodendrogenesis and myelination after white matter injury in premature infants (Scafidi et al., 2014). Therefore, the identification of TACE as an essential modulator of this pathway in OL lineage cells elevates its relevance in OL cell biology and CNS myelination. Although the relevance of EGFR in OL cell development and regeneration during remyelination has been established, the upstream modulators of EGFR in OL lineage cells had not been described before. Our study identifies TACE as the main metalloproteinase responsible for the shedding of EGFR ligands in the developing SCWM, suggesting that TACE may also be involved in EGFR ligands shedding under demyelinating conditions and modulate the regenerative capacity of EGFR signaling in OL lineage cells during remyelination. Although the 
environmental conditions and cellular interactions extremely differ between postnatal development and demyelinating conditions, further studies will define the potential role of TACE in modulating OL regeneration under demyelinating conditions. Thus, this study opens the possibility that manipulation of TACE functionality may impact the development of cellbased strategies that promote remyelination in demyelinating disorders.

In summary, the phenotype observed after TACE depletion in OPs suggests an autonomous and essential role of this metalloproteinase in OL lineage cells during oligodendrogenesis and SCWM myelination. We identify for the first time a critical role for TACE in modulating the cleavage of EGFR ligands and EGFR activation in OL lineage cells to sustain cell survival and OP proliferation during the critical periods of postnatal development and SCWM myelination (Fig. 8). Our study opens new avenues for therapeutic intervention in myelin disorders by manipulating EGFR signaling through TACE activation.

\section{References}

Aguirre A, Gallo V (2007) Reduced EGFR signaling in progenitor cells of the adult subventricular zone attenuates oligodendrogenesis after demyelination. Neuron Glia Biol 3:209-220. CrossRef Medline

Aguirre A, Rizvi TA, Ratner N, Gallo V (2005) Overexpression of the epidermal growth factor receptor confers migratory properties to nonmigratory postnatal neural progenitors. J Neurosci 25:11092-11106. CrossRef Medline

Aguirre A, Dupree JL, Mangin JM, Gallo V (2007) A functional role for EGFR signaling in myelination and remyelination. Nat Neurosci 10:9901002. CrossRef Medline

Aguirre A, Rubio ME, Gallo V (2010) Notch and EGFR pathway interaction regulates neural stem cell number and self-renewal. Nature 467:323-327. CrossRef Medline

Ardito CM, Grüner BM, Takeuchi KK, Lubeseder-Martellato C, Teichmann N, Mazur PK, Delgiorno KE, Carpenter ES, Halbrook CJ, Hall JC, Pal D, Briel T, Herner A, Trajkovic-Arsic M, Sipos B, Liou GY, Storz P, Murray NR, Threadgill DW, Sibilia M, et al. (2012) EGF receptor is required for KRAS-induced pancreatic tumorigenesis. Cancer Cell 22:304-317. CrossRef Medline

Blobel CP (2005) ADAMs: key components in EGFR signalling and development. Nat Rev Mol Cell Biol 6:32-43. CrossRef Medline

Edwards DR, Handsley MM, Pennington CJ (2008) The ADAM metalloproteinases. Mol Aspects Med 29:258-289. CrossRef Medline

Emery B (2010) Regulation of oligodendrocyte differentiation and myelination. Science 330:779-782. CrossRef Medline

Fahlström A, Yu Q, Ulfhake B (2011) Behavioral changes in aging female C57BL/6 mice. Neurobiol Aging 32:1868-1880. CrossRef Medline

Fancy SP, Chan JR, Baranzini SE, Franklin RJ, Rowitch DH (2011) Myelin regeneration: a recapitulation of development?. Annu Rev Neurosci 34: 21-43. CrossRef Medline

Franklin RJ, Ffrench-Constant C (2008) Remyelination in the CNS: from biology to therapy. Nat Rev Neurosci 9:839-855. CrossRef Medline

Franzke CW, Cobzaru C, Triantafyllopoulou A, Löffek S, Horiuchi K, Threadgill DW, Kurz T, van Rooijen N, Bruckner-Tuderman L, Blobel CP (2012) Epidermal ADAM17 maintains the skin barrier by regulating EGFR ligand-dependent terminal keratinocyte differentiation. J Exp Med 209:1105-1119. CrossRef Medline

Fulton D, Paez PM, Campagnoni AT (2010) The multiple roles of myelin protein genes during the development of the oligodendrocyte. ASN Neuro 2:e00027. CrossRef Medline

Gonzalez-Perez O, Romero-Rodriguez R, Soriano-Navarro M, GarciaVerdugo JM, Alvarez-Buylla A (2009) Epidermal grocontrol h factor induces the progeny of subventricular zone type B cells to migrate and differentiate into oligodendrocytes. Stem Cells 27:2032-2043. CrossRef Medline

Horiuchi K, Le Gall S, Schulte M, Yamaguchi T, Reiss K, Murphy G, Toyama Y, Hartmann D, Saftig P, Blobel CP (2007) Substrate selectivity of epidermal grocontrol $\mathrm{h}$ factor-receptor ligand sheddases and their regulation by phorbol esters and calcium influx. Mol Biol Cell 18:176-188. Medline
Ivkovic S, Canoll P, Goldman JE (2008) Constitutive EGFR signaling in oligodendrocyte progenitors leads to diffuse hyperplasia in postnatal white matter. J Neurosci 28:914-922. CrossRef Medline

Jackson LF, Qiu TH, Sunnarborg SW, Chang A, Zhang C, Patterson C, Lee DC (2003) Defective valvulogenesis in HB-EGF and TACE-null mice is associated with aberrant BMP signaling. EMBO J 22:2704-2716. CrossRef Medline

Jangouk P, Dehmel T, Meyer Z, Hörste G, Ludwig A, Lehmann HC, Kieseier BC (2009) Involvement of ADAM10 in axonal outgrocontrol h and myelination of the peripheral nerve. Glia 57:1765-1774. CrossRef Medline

Kveiborg M, Instrell R, Rowlands C, Howell M, Parker PJ (2011) PKC $\alpha$ and PKC $\delta$ regulate ADAM17-mediated ectodomain shedding of heparin binding-EGF through separate pathways. PLoS One 6:e17168. CrossRef Medline

La Marca R, Cerri F, Horiuchi K, Bachi A, Feltri ML, Wrabetz L, Blobel CP, Quattrini A, Salzer JL, Taveggia C (2011) TACE (ADAM17) inhibits Schwann cell myelination. Nat Neurosci 14:857-865. CrossRef Medline

Liu J, Dietz K, DeLoyht JM, Pedre X, Kelkar D, Kaur J, Vialou V, Lobo MK, Dietz DM, Nestler EJ, Dupree J, Casaccia P (2012) Impaired adult myelination in the prefrontal cortex of socially isolated mice. Nat Neurosci 15:1621-1623. CrossRef Medline

Luetteke NC, Phillips HK, Qiu TH, Copeland NG, Earp HS, Jenkins NA, Lee DC (1994) The mouse waved-2 phenotype results from a point mutation in the EGF receptor tyrosine kinase. Genes Dev 8:399-413. CrossRef Medline

Luo X, Prior M, He W, Hu X, Tang X, Shen W, Yadav S, Kiryu-Seo S, Miller R, Trapp BD, Yan R (2011) Cleavage of neuregulin-1 by BACE1 or ADAM10 protein produces differential effects on myelination. J Biol Chem 286:23967-23974. CrossRef Medline

Miron VE, Kuhlmann T, Antel JP (2011) Cells of the oligodendroglial lineage, myelination, and remyelination. Biochim Biophys Acta 1812:184193. CrossRef Medline

Nave KA (2010) Myelination and support of axonal integrity by glia. Nature 468:244-252. CrossRef Medline

Nave KA, Trapp BD (2008) Axon-glial signaling and the glial support of axon function. Annu Rev Neurosci 31:535-561. CrossRef Medline

Palazuelos J, Ortega Z, Díaz-Alonso J, Guzmán M, Galve-Roperh I (2012) CB2 cannabinoid receptors promote neural progenitor cell proliferation via mTORC1 signaling. J Biol Chem 287:1198-1209. CrossRef Medline

Palazuelos J, Klingener M, Aguirre A (2014) TGF $\beta$ signaling regulates the timing of CNS myelination by modulating oligodendrocyte progenitor cell cycle exit through SMAD3/4/FoxO1/Sp1. J Neurosci 34:7917-7930. CrossRef Medline

Peschon JJ, Slack JL, Reddy P, Stocking KL, Sunnarborg SW, Lee DC, Russell WE, Castner BJ, Johnson RS, Fitzner JN, Boyce RW, Nelson N, Kozlosky CJ, Wolfson MF, Rauch CT, Cerretti DP, Paxton RJ, March CJ, Black RA (1998) An essential role for ectodomain shedding in mammalian development. Science 282:1281-1284. CrossRef Medline

Pruessmeyer J, Ludwig A (2009) The good, the bad and the ugly substrates for ADAM10 and ADAM17 in brain pathology, inflammation and cancer. Semin Cell Dev Biol 20:164-174. CrossRef Medline

Rivers LE, Young KM, Rizzi M, Jamen F, Psachoulia K, Wade A, Kessaris N, Richardson WD (2008) PDGFRA/NG2 glia generate myelinating oligodendrocytes and piriform projection neurons in adult mice. Nat Neurosci 11:1392-1401. CrossRef Medline

Sagane K, Hayakawa K, Kai J, Hirohashi T, Takahashi E, Miyamoto N, Ino M, Oki T, Yamazaki K, Nagasu T (2005) Ataxia and peripheral nerve hypomyelination in ADAM22-deficient mice. BMC Neurosci 6:33. CrossRef Medline

Sahin U, Weskamp G, Kelly K, Zhou HM, Higashiyama S, Peschon J, Hartmann D, Saftig P, Blobel CP (2004) Distinct roles for ADAM10 and ADAM17 in ectodomain shedding of six EGFR ligands. J Cell Biol 164: 769-779. CrossRef Medline

Scafidi J, Hammond TR, Scafidi S, Ritter J, Jablonska B, Roncal M, SzigetiBuck K, Coman D, Huang Y, McCarter RJ Jr, Hyder F, Horvath TL, Gallo $\mathrm{V}$ (2014) Intranasal epidermal grocontrol h factor treatment rescues neonatal brain injury. Nature 506:230-234. CrossRef Medline

Scheller J, Chalaris A, Garbers C, Rose-John S (2011) ADAM17: a molecular switch to control inflammation and tissue regeneration. Trends Immunol 32:380-387. CrossRef Medline 
Sternlicht MD, Sunnarborg SW, Kouros-Mehr H, Yu Y, Lee DC, Werb Z (2005) Mammary ductal morphogenesis requires paracrine activation of stromal EGFR via ADAM17-dependent shedding of epithelial amphiregulin. Development 132:3923-3933. CrossRef Medline

Sun Y, Goderie SK, Temple S (2005) Asymmetric distribution of EGFR receptor during mitosis generates diverse CNS progenitor cells. Neuron 45:873-8786. CrossRef Medline

Tress O, Maglione M, May D, Pivneva T, Richter N, Seyfarth J, Binder S, Zlomuzica A, Seifert G, Theis M, Dere E, Kettenmann H, Willecke K (2012) Panglial gap junctional communication is essential for maintenance of myelin in the CNS. J Neurosci 32:7499-747518. CrossRef Medline

Wakatsuki S, Yumoto N, Komatsu K, Araki T, Sehara-Fujisawa A (2009) Roles of meltrin- $\beta /$ ADAM19 in progression of Schwann cell differentiation and myelination during sciatic nerve regeneration. J Biol Chem 284: 2957-2966. CrossRef Medline
Weber S, Saftig P (2012) Ectodomain shedding and ADAMs in development. Development 139:3693-3709. CrossRef Medline

Yamazaki Y, Hozumi Y, Kaneko K, Fujii S, Goto K, Kato H (2010) Oligodendrocytes: facilitating axonal conduction by more than myelination. Neuroscientist 16:11-18. CrossRef Medline

Yang P, Baker KA, Hagg T (2006) The ADAMs family: coordinators of nervous system development, plasticity and repair. Prog Neurobiol 79:73-94. CrossRef Medline

Yuan X, Chittajallu R, Belachew S, Anderson S, McBain CJ, Gallo V (2002) Expression of the green fluorescent protein in the oligodendrocyte lineage: a transgenic mouse for developmental and physiological studies. J Neurosci Res 70:529-545. CrossRef Medline

Zhu X, Bergles DE, Nishiyama A (2008) NG2 cells generate both oligodendrocytes and gray matter astrocytes. Development 135:145-157. Medline 